\title{
FORESTRY IN THE UNITED STATES.
}

\section{DEPARTMENT OF AGRICULTURE.}

Miscellaneous.

Special Report No. I.

\section{ADDRESS}

OF TIIE

HON. GEO. B. LORING,

U. S. COMMISSIONER OF AGRICULTURE,

BEFORE THE

\section{AMERICAN FORESTRY CONGRESS,}

SAINT PAUL, MINNESOTA,

AUGUST 8, 1883.

WA SHINGTON:

GOVERNMENT PRINTING OFFICE.

1883 . 


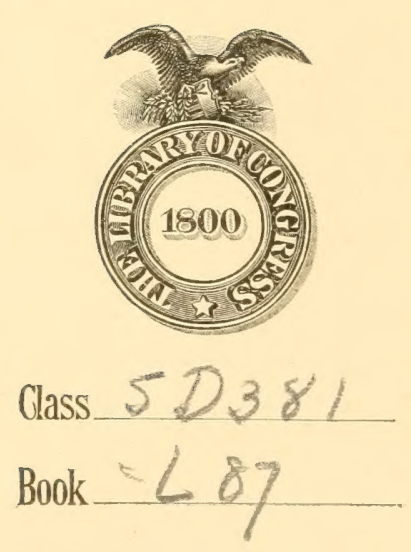








\section{DEPARTMENT OF AGRICULTURE.}

\section{ADDRESS}

OF THH

\section{HON. GEO. B. LORING,}

U. S. COMMISSIONER OF AGRICULTURE,

BEFORE THE

\section{AMERICAN FORESTRY CONGRESS,}

SAINT PAUL, MINNESOTA,

AUGUST 8, 1883.

\section{WASHINGTON:}

GOVERNMENT PRINTING OFFICE.

1883. 


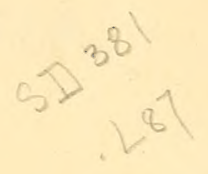

IAN 131803 


\section{A I) D RESS}

\section{THE A IERIOAN FORESTRY CONGRESS.}

Genthenen: When I had the honor of addressing an assembly of those interested in promoting the cultivation and preservation of forests in this country, and in ornamenting our cities and towns by the planting of trees in their parks and along the highways, now a year ago, I dwelt largely on the value and importance of providing in every way for the gratification of our refined tastes and for increasing the popular sense of beauty. I did this as preliminary to the more practical work which called that assembly together, and as an appeal to the strongest motive man has to engage in the business of providing for his wants and surrounding himself with the comforts and luxuries which prosperity secures. At this time I propose to confine myself strictly to the condition of forests in this country, and to such suggestions as may occur to me with regard to their increase, preservation, and economical use.

And first as to the increase of our forests. In this work both nature and art are engaged. The "forests primeval" meet man wherever he advances to the occupation of new lands best adapted to feed and clothe him and best fitted for agricultural labor and production. His primary work is to remove this great vegetable growth, whose condition indicates the quality of the soil he proposes to cuitivate. If he pauses in his work the forests return to their accustomed place. In the older States many acres which half a century ago were used for pasturage or tillage are now covered with forest growths, and many timber lands which bave once supplied the forest products are now hastening to supply a new crop. The acreage of woodland is undoubtedly increasing in those sections where farming has become unprofitable either through exhaustion of the soil or through a change in the locality and demands of the markets. In the strictly lumbering States this is also true. While the deserted, remote, and mountain farms in Massachusetts are rapidly "growing up to wood," the woodlands of Maine and Michigan and many another lumbering State are growing a new crop, which in a quarter of a century will be more valuable than the original growth, although much reduced in size. The young pine and spruce forests of the north, covering acres of land once occupied by their sturdy progenitors, are full of promise and beauty. In other sections of the country, 
lands, which have for ages been bare of trees while exposed to annual prairie fires, are, under the protection of man, producing rapid growths of wood. As the settler guards his fields against fires and cattle, trees spring up, and especially along the water-courses may be seen forest belts where an entire absence of trees had been the law for many generations of men. Wherever the land is protected, therefore, whether it be the location of old forests, or bare spots adapted to tree-growing where forests have been hitherto unkuown, nature is busily engaged in producing wood and in bringing back the forest grow th which welcomes advancing man as he goes on in his work of civilization.

In addition to this natural increase, much has been done in many of the States in tree-plantiug, and much more ought to be done. The establishment of "arbor days" and the inducements held out by legislation hive operated very favorably on the work of what is called village improvement, and on an agricultural attention to the cultivation of trees as a crop. And this business has increased with very considerable rapidity in some of our best farming States. In Minnesota, for instance, the number of acres planted on "arbor day" in 1878 was 811 ; in 1882 the number was 1,184; and the whole number of acres planted increased from 18,029 in 1878, to 38,45s in 1882. Work similar to this is done in Iowa, Nebraska, and Dakota, as well as in Ohio, Michigan, Illinois, and Kansas. In Nebraska, the number of acres of cultivated woodland has reached $107, \mathbf{1 3 8}$, as against 19,695 acres of natural inerease. These are small beginnings, it is true, but ther are entitled to our most careful consideratiou as the commencement of an enterprise which, when properly conducted, will undoubtedly constitute an important branch of American agriculture.

Tree-culture ought now to receive our most careful attention. It is time that the skill which has been applied to the cultivation of our great cereal crops, to cotton, rice, tobacco, and all the profitable products of the soil, such as grass and regetables and fruits of every description, should be applied also to the growing of wood as a farm product. To the clioice of forest trees adapted to each locality; to the selection of land which can most properly be devoted to trees, considering its fitness or unftuess for any other crop on account of quality and situation, whether near to or remote from the farm buildings, whether useful or not for pasturage and tillage; to the best methods of cultivation, whether by seeding or planting from nurseries; to the best method of securing a speedy return-to all these points the attention of practical and investigating farmers should be carefully and systematically turned. The profit of the crop can, I presume, be no longer questioned. Waste lands inclosed and left to nature have produced in wood a very large return for the investment. Why should not land subjected to the well. directed art of the cultivator produce just as good a result? For the purpose of encouraging this enterprise it is important that Government should lend its aid in every legitimate way until the wood crop is recog- 
nized exactly as are the great staple crops of the country. If a bounty is legitimate and useful in any case, it certainly would be in this. The

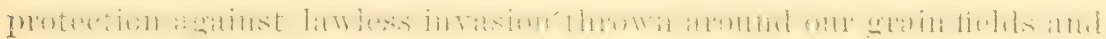

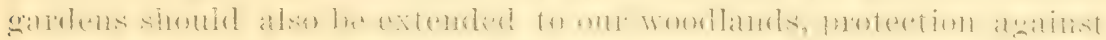
depredation, wanton fires, and stray cattle. 'The rifling of a forest should he as penal an offeuse as the riflug of an orehard. Orer forestcorererl publie lauds and orer forest plantations, against the careless destruction of the settler on the one, and the trespass of the ontlaw on the other, should the strong arm of the law be constantly and rigorously exturilerl.

TIIE VALUE OF TIIS INDLSTRY.

In order that I may impress upon fou the value of this industry I will ask your attention to its extent in our comntry, which corers such a vast area. I do this in order to impress mpon your miuds not only

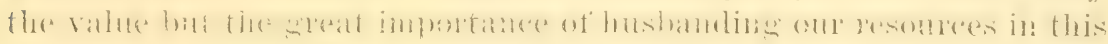
direction in riew of the constantly increasing demand for on forest products in all their rariety. The forest lauds of the United States

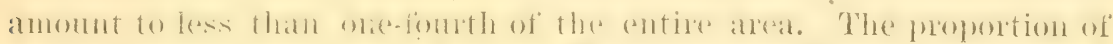

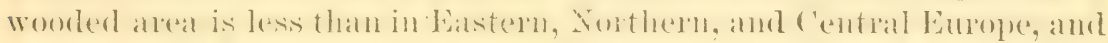
is very unequally distributed. Norway has two-thirds of its area

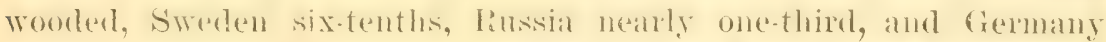
nearly one-fometh. The comntres having less forest areas, alramged in orlex of proportion, fiom 18 down to 5 per ent., are lielgium, France,

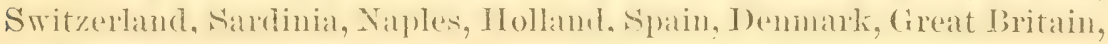
and Portugal.

Originally the Southern, Mirlule, and kastrin sitates were entirely

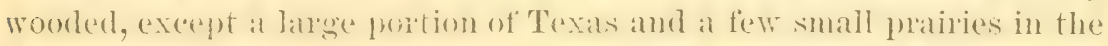
Sontlawest. Simall areals of momntain shloles among the Alleghenies

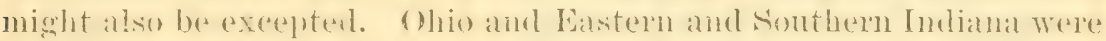
wooded, and the northern portions of the Lake States.

West of the line of parires, rumbing southwest throngh Indiana,

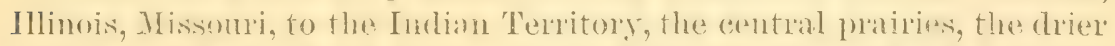
jlains, ans much of the southern belt of the l'acifie shope ane destitute of wool. The streams in all the great resion ale more or less finged with trees of some sort, and the higher momentains on the protected

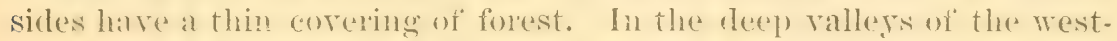

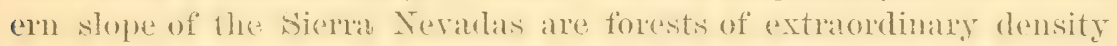

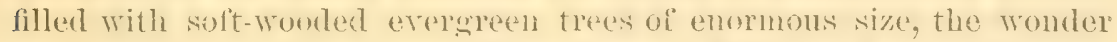

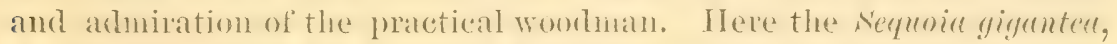
or big tree, flourishes in isolaterl patehes, while the const range is the home of the Sequoia sempervirens or redrood.

From Nontl Carolina to Louisiana nearly six-tenths of the farm area is wooded, though much of the area thinly, and part of it has becu culled and is in secomb growth. Inchuling mocenpierl areas not in farms 


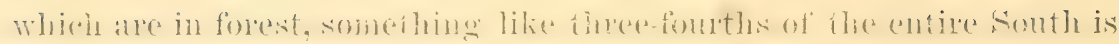
wooder.

There are counties in the Sonth that were ten Jears ago almost unbroken forest. More than nine-tenths of the area of Brunswick, North Carolina, were then wooded, and almost as large a proportion of Beau. fort, Craven, Onslom, New Hanover, and Bladen. A similar prepon-

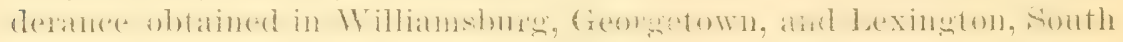
Carolina; and in Camden, Charlton, Clinch, and others in Georgia. In

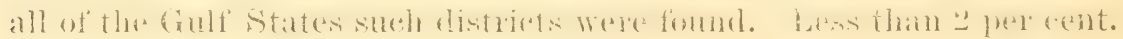
of Newton County, in Eastem Texas, was cleared. To-day the proportion of woodland is but little less. On the farm areas of Georgia the percentage of forests has increased from 55 to 59 on account of taking tro or three millions of primitive forests into the farm area.

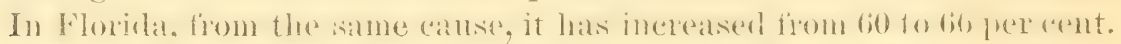

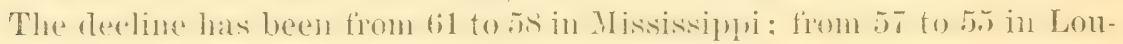
isiana. It has increased from 42 to 44 in Texas; aud nearly one inmdred counties show from 10 to $S 0$ per cent. in wood. The wealth of

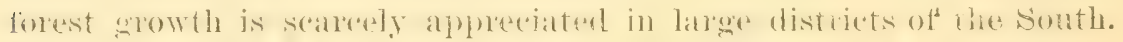

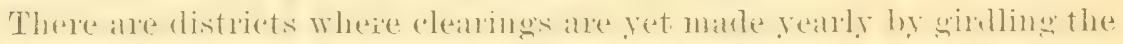
treses in the summer for plantige among the boles standing hare and blackened. Every winter a log-rolling disposes of the trunks that fill, until decay and fire have eleared the field. And it is not long since a

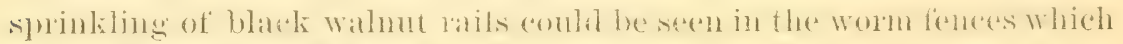

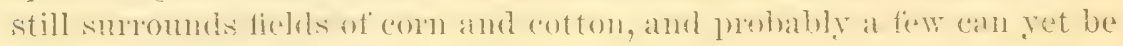
found.

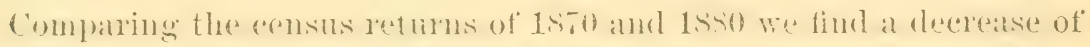

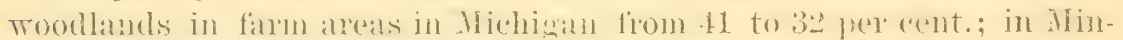
nesota from 21 to 15, and in Iowa from 16 to 11 per cent. In Nesurastia, tree-planting has changed the record from 3 to 10 per cent. From the increase of farms in the wooded area, $1 \mathrm{Viscousin}$ has 31 instead of 29 per cent. The comparison is thus tabulated:

\begin{tabular}{|c|c|c|c|c|c|c|}
\hline \multirow[b]{2}{*}{ States. } & \multicolumn{3}{|c|}{1880.} & \multicolumn{3}{|c|}{1870.} \\
\hline & $\begin{array}{l}\text { Aeres in } \\
\text { farms. }\end{array}$ & $\begin{array}{l}\text { Acres in } \\
\text { Troodland. }\end{array}$ & 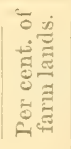 & $\begin{array}{l}\text { Acres in } \\
\text { farms. }\end{array}$ & $\begin{array}{c}\text { Acros in } \\
\text { woodland. }\end{array}$ & 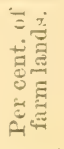 \\
\hline 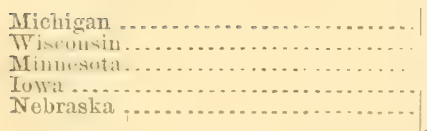 & $\begin{array}{r}13,807,240 \\
15,35,118 \\
1: 411,119 \\
21,73,700 \\
9,944,826\end{array}$ & 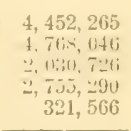 & $\begin{array}{r}32 \\
31 \\
1.7 \\
11 \\
3\end{array}$ & 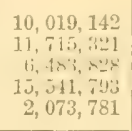 & 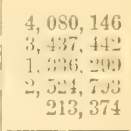 & $\begin{array}{l}41 \\
29 \\
21 \\
16 \\
10\end{array}$ \\
\hline Total . . . . . . . . . . . . . & $77,260,903$ & $14,327,893$ & 18 & $45,833,865$ & $11,592,054$ & 25 \\
\hline
\end{tabular}




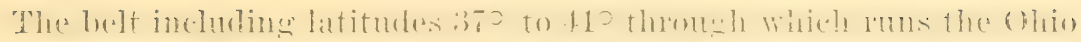

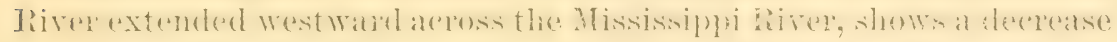
from 31 to 26 per cent.; greatest in Ohio and Indiana, as follows:

1880.

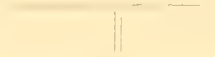

1870

States.

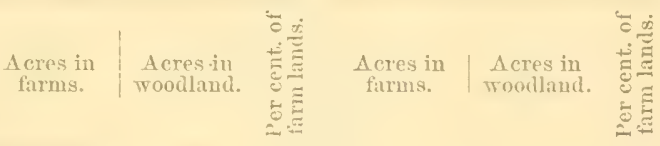

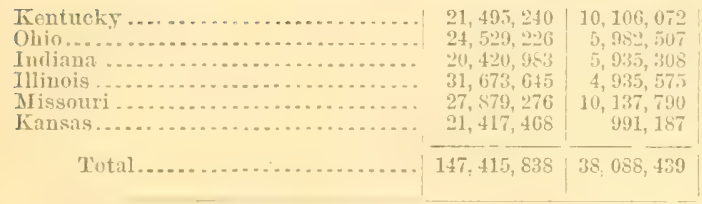

In the eastern section, Maine shows an increase from new farms in Aroostook County and other northern comnties, but it has been de-

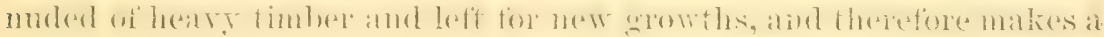
deceptive showing. New York shows a decrease from 26 to 22 per cent., and Peunsylvania from 32 to 29, as follows:

1880.

States.

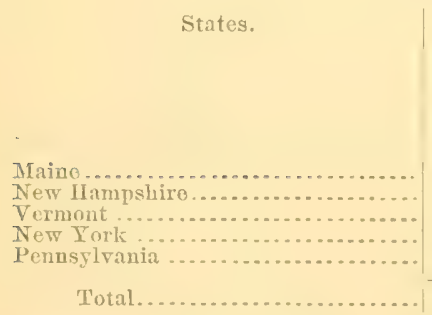

1870 .

\begin{tabular}{|c|c|c|c|c|c|}
\hline $\begin{array}{l}\text { Acres in } \\
\text { farms. }\end{array}$ & $\begin{array}{c}\text { Aeres in } \\
\text { woodland. }\end{array}$ & 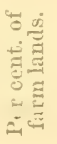 & $\begin{array}{l}\text { Acres in } \\
\text { farms. }\end{array}$ & $\begin{array}{l}\text { Acres in } \\
\text { woodland. }\end{array}$ & 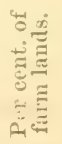 \\
\hline $\begin{array}{r}6,552,578 \\
3,721,173 \\
4,882,588 \\
23,780,754 \\
19,791,341\end{array}$ & $\begin{array}{l}2,682,296 \\
1,296,529 \\
1,503,467 \\
5,195,795 \\
5,810,331\end{array}$ & $\begin{array}{l}41 \\
35 \\
31 \\
22 \\
29\end{array}$ & $\begin{array}{r}5,838,058 \\
3,605,994 \\
4,528,804 \\
22,190,810 \\
17,934,200\end{array}$ & $\begin{array}{l}2,224,740 \\
1,047,090 \\
1,386,934 \\
5,679,870 \\
5,740,864\end{array}$ & $\begin{array}{l}38 \\
29 \\
31 \\
26 \\
32\end{array}$ \\
\hline $58,7: 38,434$ & $16,488,418$ & 28 & $51,157, \varepsilon 66$ & $10,079,498$ & 30 \\
\hline
\end{tabular}

Taking the States loy groups the ineruality of forest distribution is strikingly shown. The following statement divides the wooklambls reported on farm areas as follows:

States.

New England

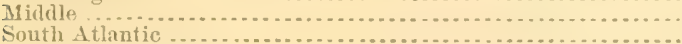

Gulf and Southern

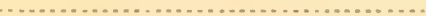

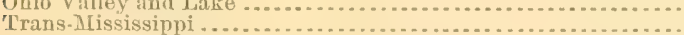

Pacific

Rocky Mountain

Total.

\begin{tabular}{c|c|c}
$\begin{array}{c}\text { Acres in } \\
\text { farms. }\end{array}$ & $\begin{array}{c}\text { Acres in } \\
\text { woodland. }\end{array}$ & $\begin{array}{c}\text { Per cent. } \\
\text { of farm } \\
\text { land. }\end{array}$
\end{tabular}

\begin{tabular}{r|r|r}
$21,483,772$ & $7,315,730$ & 34 \\
$47,592,113$ & $11,993,317$ & 25 \\
$90,117,393$ & $49,339,653$ & 55 \\
$112,004,983$ & $59,078,032$ & 53 \\
$137,473,231$ & $42,360,123$ & 31 \\
$97,397,289$ & $16,296,559$ & 17 \\
$21,339,316$ & $3,115,924$ & 15 \\
$8,673,738$ & 816,406 & 09 \\
\hline $536,081,835$ & $190,255,744$ & 35
\end{tabular}


CHANGES BY YEARS.

The following tables give a list of the States showing changes of ten sears both in farm and woodland areas:

Maine

New Hampshire.

Vermont

Mrassachuset ts.

Thode Island

Connectiont.

\section{New Eugland.}

New Tork

Xew Ji-rey y

Peunsylrauia

Delaware...

\section{Middle}

Maryland

Virginia

North Carolina.

South Carolin?

Georgia

Florida.

Sonth Atlantic.

Alabama

Mississippi

Louisiana.

Texas.

Arkansas

Tenuessee

Gulf and Southern

West Virginia

Kentucky...

Ohio

Mrichigan

Indiana.

Illinois......

Wisconsin

Ohio Valley and Lake

Minnesota

Iowa.

Missouri.

Kansas.

Nebraska

Trans-Mississippi.

Coloradò

Arizona.

Tilaho.

Montane.

New Mexico

Utah.

WVashington

Wv voming.

Indian

Rocky Mountain.

California.

Oregon.

Pacific Coast.

$3,115,924$

$5,195,795$

$5,810,331$ 279,099

$11,993,317$ 34

$1,634,019$

9, 126, 601

$13,808,086$

$-5,121$

$15,269,225$

$2,186,601$

$49,339,653$

10, $4: 30,727$

$9,144,323$

$4,557,332$

$15,851,365$

$7,861,409$

$11,232,876$

$59,078,032$

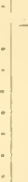

$6,180,350$

$10,106,072$

$5,982,507$

4,452,265

$5,935,308$

$4,935,575$

4, 768,046

$42,360,123$

$2,030,726$

2, 755,290

$10,137,790$ 991, 187 321,566

\begin{tabular}{|r|c}
\hline $16,236,559$ & 17 \\
\hline 44,117 & $=\frac{1}{4}$ \\
13,399 & 10 \\
80,264 & 2 \\
11,892 & 4 \\
3,678 & 1 \\
219,224 & 35 \\
2,305 & 0.4 \\
437,696 & 31 \\
510 & 0.4 \\
3,321 & 18 \\
\hline 816,466 & 9 \\
\hline $1,672,810$ & 10 \\
\hline $1,424,417$ & 34 \\
\hline 18,697 & 4 \\
\hline $3,115,924$ & 15 \\
\hline $190,255,744$ & 35 \\
\hline
\end{tabular}




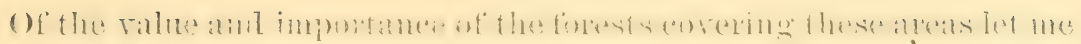

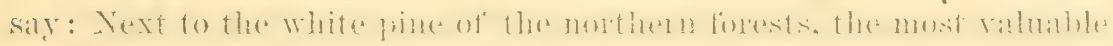
tree is undoubtedly the Pinus australis, or long-ieafed pine of the southeru coast lauds, forming a belt of varying breadth, up to 100 and 150 miles from the Athatic and Gulf shores. It is the Georgia pime of builders, preferred for hooring and heary frume-nork, and is still found in pristine vigor and abundance over a large area from Noxfolk to Calveston. These pine lands are now eagerly sought for by American and English capitalists, are rapidly taken up for manufacturing operations or on speculative account, and are rising in ralue. They have been held for many years by the General Gorerment at prices ranging from 12 cents to $\$ 1.25$ per acre, the former being for lauds that hart been opened to market for a certain period. 'Whis is the turpentine pine of

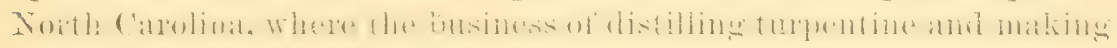
tar and rosin has long been profitable. It is also carried on, though in isolated enterprises, in other portions of this coast belt.

\section{TURPENTINE PINE.}

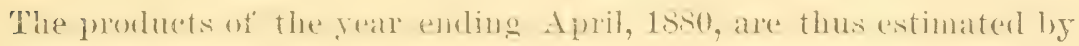
Mr. A. H. Vau Bokkelen:

States.

Turpentine. Rosin.

\begin{tabular}{|c|c|c|}
\hline 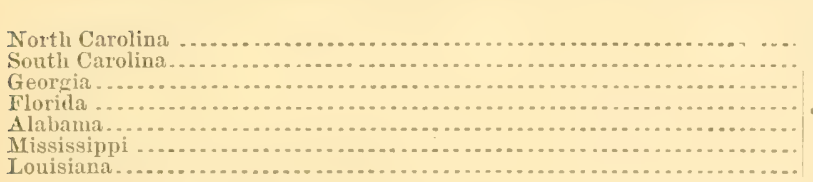 & $\begin{array}{r}\text { Gallons. } \\
6,279,200 \\
4,593,200 \\
3,151,500 \\
1,036,350 \\
2,005,000 \\
250,000 \\
250,000\end{array}$ & $\begin{array}{l}\text { Barrels. } \\
663,907 \\
-333,940 \\
277,500 \\
68,281 \\
158,482 \\
20,000 \\
20,000\end{array}$ \\
\hline Total United States.. & $17,560,300$ & $1,542,110$ \\
\hline
\end{tabular}

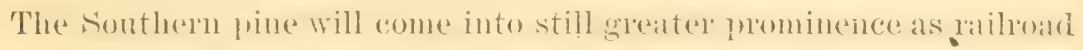
and steamboat lines extend facilitics tor tamsportation, which is now being done with great rapidity.

The condition of the pine-lumber supply of the Triterl states in connection with the statements I latve made is interesting. The destruction of this tree by fire and the ax of the settler and the lumbermani is very great. Together with the spruce it is heing maphly comsumed, and I think the following figures will show that the supply is to be obtained hereafter by allowing an exhausted region time to recuperate, while the comparatively uncut sections are resorter to for filling the domands of the market. Investigations reenelly made show that the supply of pine in New Hampsuire and Vermont is exhausted, and that the spruce lumber, at the rate the cutting is now going on, will last in the former State hut 7 years, and in the latter but 4 . In the State of Manine the pine will last 4 years aud spruce 15 years. In South Caroliua the pine forests will last 50 years at the present rate of cutting; in California, 150 years; in Arkansas, 300 years; in Pennsylvania, 15 years; in 


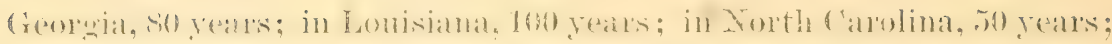
in Wisconsin, 20 years; in Michigan, 10 years; in Minnesota, 10 years; in Mississippi, 150 years; in Alabama, 90 years; in Florida, 30 years; in Texas, 250 years. That the exhansted forests in this list of States can be restored in time there is no doubt; and every means of cultivation and protection should be applier by the people and the Gorerument, both State and Federal, each in accordance with its own jurisdiction.

\section{FEARS OF A TIMBER FATINE UNFOUNDED.}

We should not forget, howerer, that while the demand for timber is

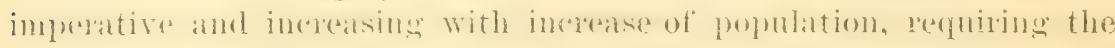
fostering expe of the fiovermment and the enlightenerl enterprise of

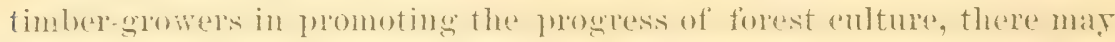
be danger of assuming too hastily a prospective timber fanine, and

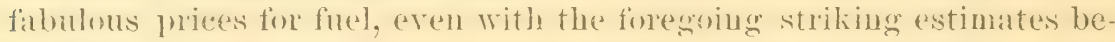
fore us.

It should be remembered that thus far the exhaustion of lumber relatesmanly to the white pine. It may bu fomm, when the weat pineries shall be eut over, that the ontcome is greater than was assumed, and

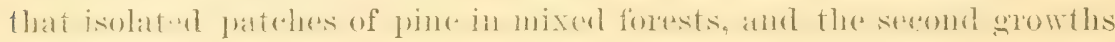
and remuants from first cuttings, may suffice to delay the threatened famine.

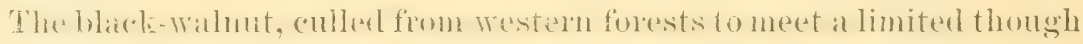

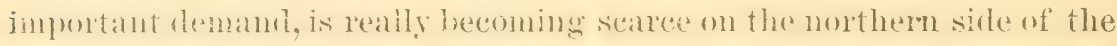
(yho Valky; lont on the southeru, along the foot-hills and in the valleys of the Appalachian range, it is abundant and almost untouched. It srows raybly in the Western states even beyoud the Missouri, and is destiued to be the source of wealth to the future tree-grower.

The millions of arese of existing forests on this great eastern chain of monntains have not yet hern consiklered in the statisties of forestry here presentéd. Their resources have never been measured, are yet com-

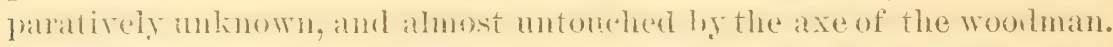

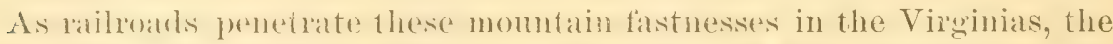
Camolinas, hentuch and lennesser, bonanzas of forest production will respond to the eall of enterprise, and enrich the proprietor-wootsman and mannficturer. In arlition to this, the white pine of Minnesota is estimated at $6,100,(100,0) 00$ feet (2xchusive of isolated timber in bireh lands

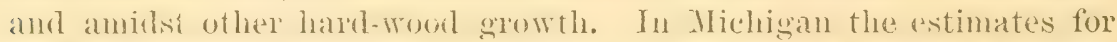

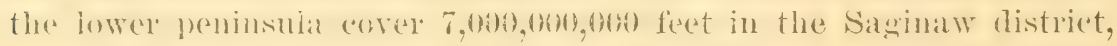

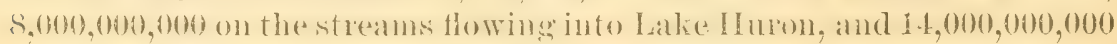

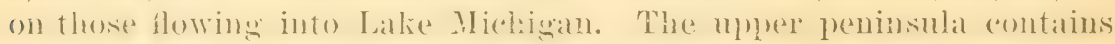
$6,(600,000,0000$ mone, making $: 3,000,0000,000$ leet in the principal pine districts of Michigan.

The great pins forests of Wisconsin are estimated to contain 1,000 ,-

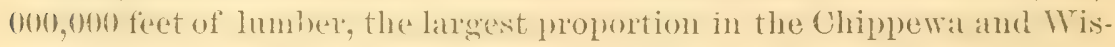

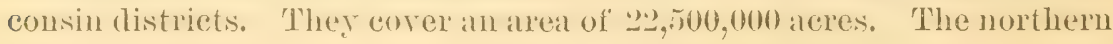


border of the pine area is less protuctive than the areas of lower latitudes. The eedar swamps of Wisconsin seattered throngh the pine belt are estimated to cover $1,365,000$ acres, and to enntain $62,800,000$ posts,

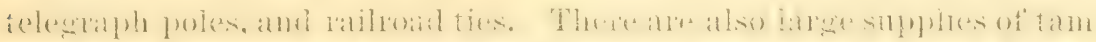

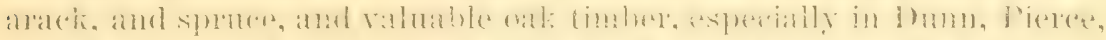

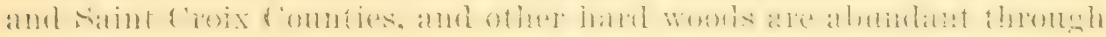
the sonthern border of the wooded districts.

The united area of the States south of Mlaryland and the Olio River

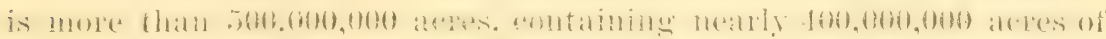
forest lands. The farm area of these States is $228,000,000$ acres, con-

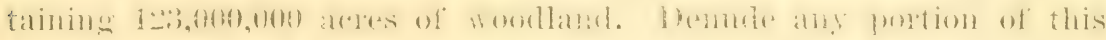

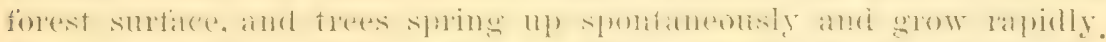

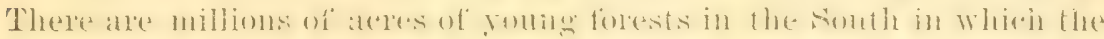

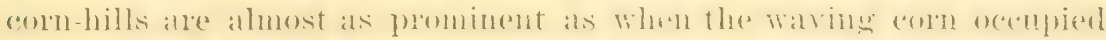

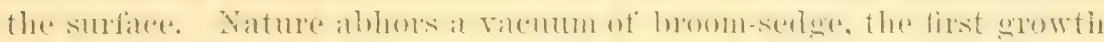

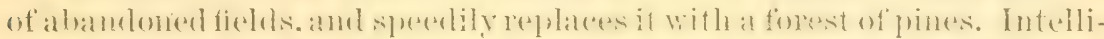

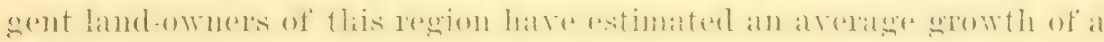
cord of wood per acre each year, or twenty cords of wood per acre in twenty years.

Is there immediate danger then of scarcity of fuel in a country where more than two-thirds of the entire area is wooded; and when

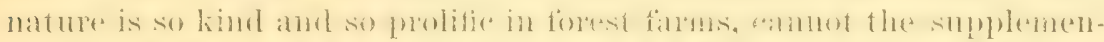

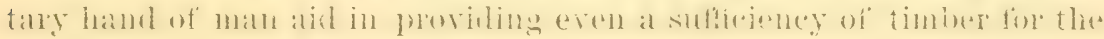
wauts of coming generations?

PRESERVATION OF FORESTS.

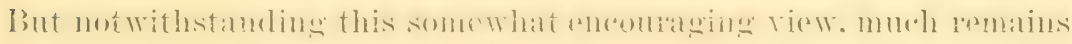
to be done for the preservation of on forests. The waste by careless

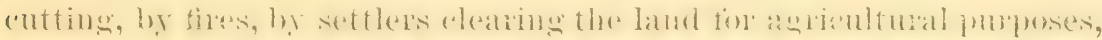

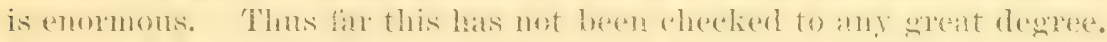

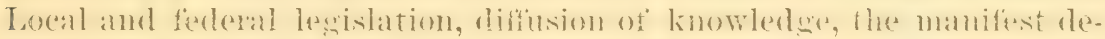

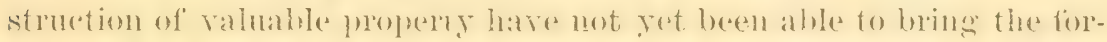

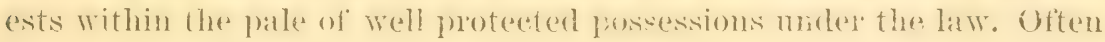
has the remerly been prononnced hy those who have deroted their lives to the study of this imlustry, and often have laws been passed which serened to affurl a remety for the existing evil. But still the work of destruetion goes on. It now remains, as it seems to me, for the public mind to be inought fo a ture nuldestambing of the value of the properety itself and of the disaster whirh would atteurl its destruction. That protection can be sivemed in the states hy associations like this, by platetical men en-

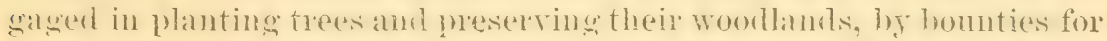
streessful tree-enlture, by the distribution inoadeast of bulletins and pamphlets, there an be no doubt. On the best method of legislation it is not easy to decide. Ibomuties based on exemption fiom taxation have not had the desiled effect, the tree-planting hatring served more as a mole of evading taxation than as a means of developing an industry 
under the stimulus of protection. And of oue comnty in Iowa it is said "the experience of the board of supervisons justifies them in the opinion that forest culture in our county would adrauce as rapilly without as with the exemption laws." On the other hand the State auditor declares that: "there can be $n$ question but that this law of our State has grately stimulated the planting of forest trees and orchards too;" and that "if advantage conld be taken of its popularity by inducing planter to set out a better elass of trees, such as ash, wahut, \&e., more good would thereby be accomplished." Connecticut, Dakota, Nerada, Pennsylyania, Rhode Island, Texas, and other States, have ali passed acts encouraging tree-planting, either by bomnty or exemption. Encouragement has also been largely offered by agricultural associations in most of the States, and great attention has been given to the proper selection of trees for each locality. The iutrodnction of new varieties of forest-trees has been carefully considered also; and the habits of trees, native and foreigu, have been made matters of the most diligent study, both by those who are gorerned by scientific zeal and those who are en-

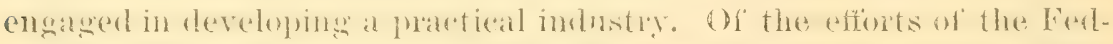

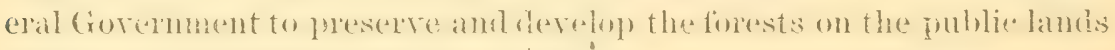
of the United States much has been said.

\section{THE TIMBER-CULTURE ACT.}

On the working of the timber-culture act it is mmeressary for me to dwell. But I think I an, with profit, submit some suggestions, made by the Land ()tfice, with regand to "timber depredations". and the laws to prevent them. On this point the Land Commissioner, in his report of 1882, says:

While much has been accomplished in the direction of suppressing the mulawf cutting and removing of timbers from the public lauds, I am of the opinion that better results can be obtained in the future; particnlarly so if some general and comprehensive law conld be passed clearly defining who may take timber from the public lands, the purposes for which it may be cut and removed, aud preseribing the punishment for unlawfully cutting, remoring, or in any way wantonly destrojing or injuring any timber growing, or being upon any of the publie lauds, or in any way causing or inciting such trespass. Such law should also establish tho terms and conditions upon which avy compromise or settlement should be authorized. A law of this nature would be more generally understood and comprehended than the several different enactments relating to this subject now in force, and could be more easily and ovenly administered.

This is recommended becanse it is diflicult to get competent and reliable special timber agents unler the existing laws, and becanise the offenses are committed too often under cover of the homestead entries fraudulently made for the purpose of securing the timber on the lands. I think the dificulty in this matter lies in the fact that no value is set upon the timber itself as a piece of Government property. It has been assumed that Government does not desire to make the timber a source of revenue or profit, and that in the survey of lands no discrimina- 
tion shonld be male on the seore of existing resourees. This polier may be wise and necessary, but it is not thrifty. Early in the history of the Government public lands were solk, as in the case of the sale to

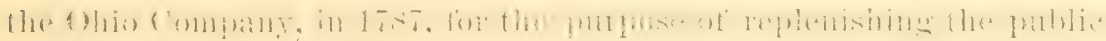
treasury. And while Congress has exerciserl great liberality in the fonation of lands for various enterprises, still the fact remains that this landed possession is of great financial importance. The time is gone by when the standing timber of the comtry, either on public or private domain, can be considered an obstruction to be removed by the ax and fire to make way for crops of another description. There is a value attached to it equal to that of any erop linown-a value which shonld in some way be considered in the transfer of public lands to settlers and purchasers. Whenever, in any way a recognized ralue is attached to the timber itself, be it large or small, its protection and preserration by the Govermment becomes a uatural consequence, and wanton destruction by the ax and tires may be prevented. Gorerument now offer's a bonuty for planting trees by its timber act, and makes no

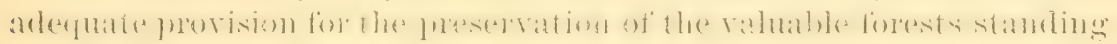
on mocenpied linds. It seems as if this case might be met by some form of legislation.

The timber-culture act Was passed March 3, 1873, amended Mareh

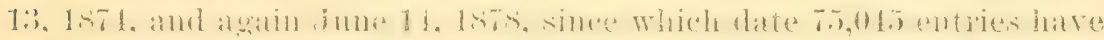

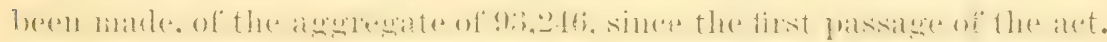

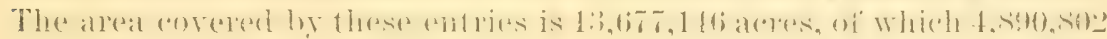

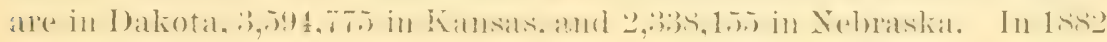

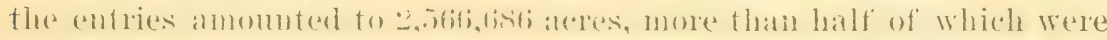
in lakota. The distribution of the agregesate entries is as follows:

States and Territories.

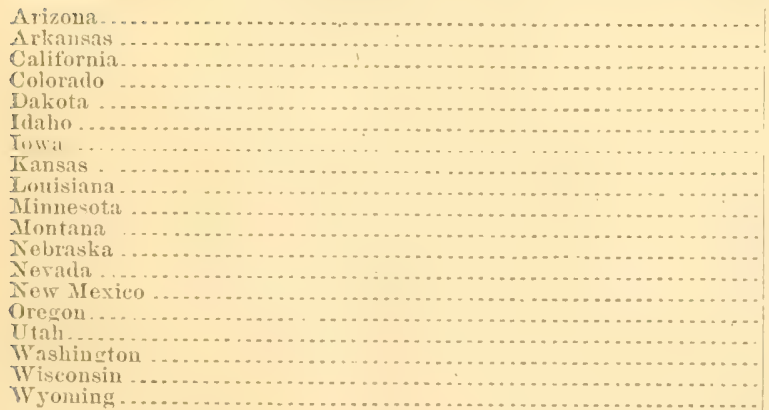

Total
Entrics.

Acres.

\begin{tabular}{|c|c|}
\hline 88 & $11,866.08$ \\
\hline 3 & 231.92 \\
\hline 1,245 & $168,413.53$ \\
\hline 31,178 & $4,890,802.15$ \\
\hline 1,089 & $141,903.25$ \\
\hline lito & $\therefore, 151,51$ \\
\hline 24,854 & $3,594,775.49$ \\
\hline 28 & $3,417.85$ \\
\hline 10,866 & $1,510,382.56$ \\
\hline 497 & $63,273.25$ \\
\hline 11) $\begin{array}{r}40.3 \\
30\end{array}$ & $\begin{array}{r}2,338,155.60 \\
4,120.00\end{array}$ \\
\hline 87 & $11,619.13$ \\
\hline 1,570 & $232,954.86$ \\
\hline 137 & $16,144.59$ \\
\hline 3,332 & $476,841.52$ \\
\hline 37 & 3,67921 \\
\hline
\end{tabular}

$93,2 1 0 \longdiv { 1 3 , 6 7 7 , 1 4 6 . 3 7 }$

TUE NECESSITY OF PRESERTING AND REPLANTING FORESTS.

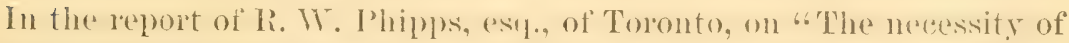
preserving and replanting forests," I find a sketch of forests and their 
management in other countries, to which I call your attention as one of the most comprehensive statements we have had on this subject. His sketch, which is here abridged, is taken from an extensive report

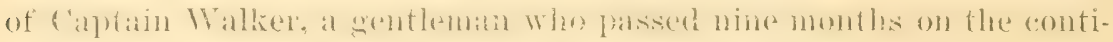
- nent, by direction of the English Govemment, for that purpose.

From Mrr. Phipps I learn that in Fanorer there are 900,000 acres of

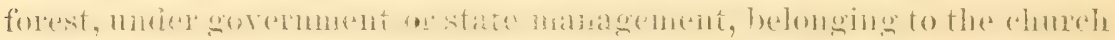
and to municipalities. 'The care and working of these forests costs

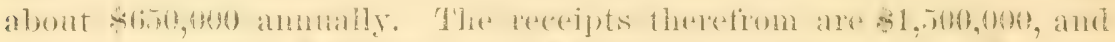

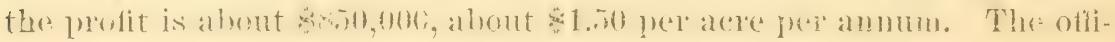
cers in charge are a forest director, an over-forest master, 20 forest masters, 112 over-1oresters having charge of districts of seven or eight thousand acres eath, fo:3 assistantolonesters. Asystematio plan for the management of the forest is alopted.

After a forest has, by thinning, planting, and so fortl, been gradually got into perfect order, the system of natural reproduction forms a great part of the German methor. It is as follows:

The rotation and periods are fixed in the working plan. For beech it is, in Hanover, 120 rears, divided into six periods of 20 5ears each-that is to say, when the forest has been bronght into order there should be nearly equal areas under crop of trees in each of the six periods, from one year to twenty, from twenty to forty, and so on. When a block arrives in the last period, felling is commenced by what is called a preparatory clearing, followed br a "clearing for light" in the first year after seed has fallen, with the object of (1) preparing the ground for the seed, (2) allowing it to germiuate, (3) affording light to the young seedlings. If there is a good seed year aud sufficient rain, the ground should be covered with seedlings in two or three rears after the first cleariug; but it is better generally to wait for a second year, and aid nature by hand-sowing, transplauting from patches of many to the barer spots, and turuing up the turf to give the seeds a better chance of germinatiug.

When the ground is well covered, the old trees are felled and carefully removed, so as to do as little damage as possible to the new erop, and the block recommences life, so to speak, nothing further being done till the first thinuing. The time allowed between the first and final clearings is from eight to fifteen years. * * * In these forests can be seen all the periods of growth-nurseries and schools for seedlings.

In Prussia there are twents millions of ares of forests, ten millions of which are private, and the remainder, with which we have more to do, state, communial, and ecclesiastical. Of these the income is $\$ 14,000,000$, and the expenses $\$ 7,500,000$, leaving $06,500,000$ clear. The forests in Prussia as in Hanorer form part of the finance department, and are peresded over by an overlund-forest-master ami ministerial director, aisled ioy a reveune conncillor and joint ministerial director, and a numerous council or boarl. There are two forest academies, ond near Berlin and one in Hanover.

There are iz provinces in P'russia, divided into 30 circles, each having an orer-forest master. These represent the forest department in local administrations, which as a board represents the forest interests in the governnent.

In order to be a forest-master, the lomest of the gazetted appoint- 


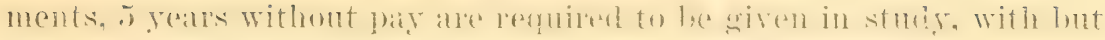
meager pay when employed, jet caudidates are numerons.

Iu some provinces the Prussiau Goverument has certain rights concerning the management of private forests; in others, none.

In Saxony the state forests are nearly 400,000 acres, workel at an.

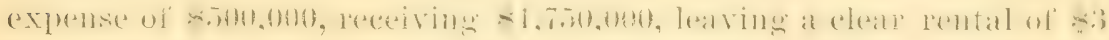
per acre. The expenditure is planting, draining, roads, implorenent

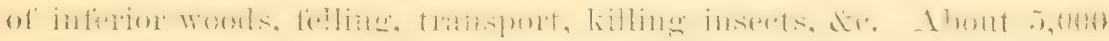
are planted yearly, at an average cost of $\$ 7.50$ per acre. The official

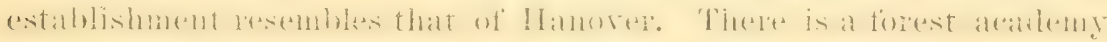
at Tharaudt with a separate stati" of professors.

In liavatia the state lonests (o) paying all expenses, about $\$ 1.50$ per acre per annmm. About 30,000 acres are planted of sown ammally, taking 35,000,000 plants and

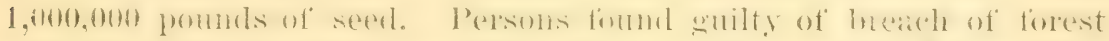

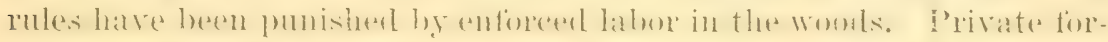

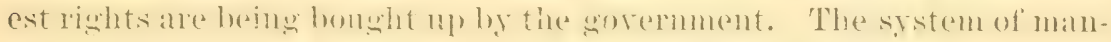
agement is much the same as that previonsly described.

In Lustria the state forests have been laregely sold to meet state ne-

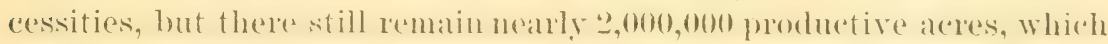

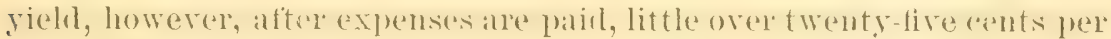
acre. The existingestablishments of forestry are not miform, hut there

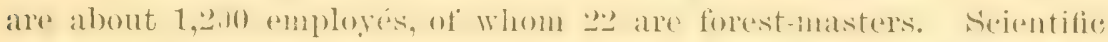

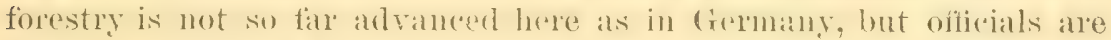
busily introduroing a reorganization, ly means of which, there is no doubt, it will be on a par with oflere states. The dustrian erown forests have been nergleceded. There has been till now no attempt at rotation of blocks, or working in periols. The present director is trying hard to change matters lor the better. He is planting up many bare or ill-corered tracts, where natural reproduction is impossible, owing to the absence of standard trees.

In the Grand Inchy of Baden there is a most interesting private forest belonging to the Prince of Furstenburesh, in the Bhack Forest. There are about 72,000 acres in charge of 19 foresters and over-foresters, who have mauy subordinates.

The administration of forests in France is intrusted to the ministy of fiuauce, and the head of the department is the director-general, assisted by two administrators, one charged with the management of the forests and the sale of the products, the other with the police of the forests and the forest laws. The forests under the management of the burean (state or commeree) are about 7, j00,000 acres. Also, there are in France 15,000,000 acres of private forests. The saw-mills in the forests are usually owned by the govermment, and hired at a certain rate to the wood merelants, who buy the enttings. The school of forestry at Nancy is said to be one of the best in the world. The French Gorernment have, at great expense, resplanted vast and almost barren dis- 


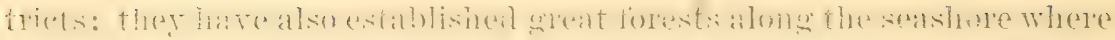
formerly the sand threatened to ilestroy mhole departments, and have averterl the evil.

In Russia, the govermment own about $330,000,000$ acres of $\pi 00 \mathrm{ds}$, and other parties $150,090,000$. Abont 40 per cent. of the country (Russia in Europe) is timbered. The immense goverument woods have been placed under the care of the minister of public domains, who has a director of the forest department, and the organization of the service is rery complete. Two special sehosls of a grienlture and forestry have been established; one at St. Petersburg, and oue near Moscow.

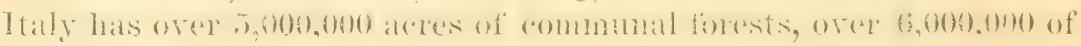

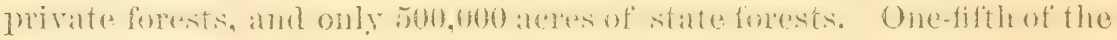
land is in forest.

In Switzerland, the waste of forests has been more rapid and destructive thau any other country in Europe, and in none, perhaps, has this been followed by urore disastrous results. Pnblic attention has, however, been thoroughly awakemed, and active measures are in progress to remedy, as far as may be, these evils. The cantons which have charge of these operations have for some time, at great expense, been constructing works to coutrol the streams, and planting trees wherever practicable.

The description of the forests in the bitish lske as given by captain Talker, from whom Mr. Phipls oblaned his lacts, is most interesing, and shows, as do those to which I have already referred, that the busi-

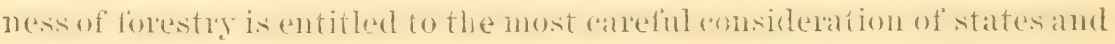
individuals.

\section{VARIETY AND AGE.}

In the practical work of planting forest trees there womld seem to be a propriety in following the example of nature and giving varisty, mix. ing teess of early maturity with those of great longerity, that the former may be cot when the great size of the latter should command an ampler space. 'Iluns after the usmal consecutive thimnings for hoop-poles,

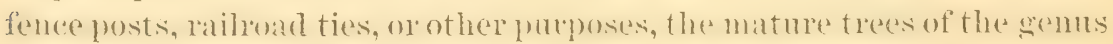

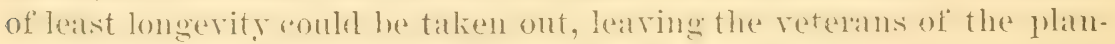
tation to mature their more raluable crop of heary timber.

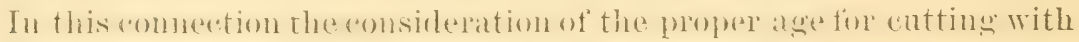
profit is important. Mr. Mrichie reports his recent observation of a plautation in Great Britain sixty-five years old, partly cut down, in which s.j pere cent. of a growth of mixed hatrel wooks was deceased from over lipeness. The plantation should have heen ent at fifty geals. The

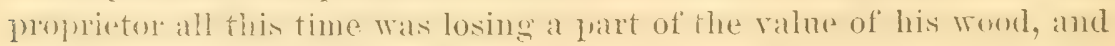

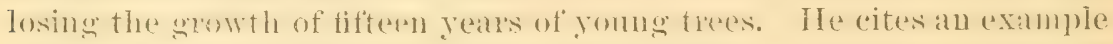
of an ash growth the root cuts of which were "tough as whalebone" at fifty-fire yeals, while at serenty-fire all tomghess had disilpueared aud more than half its value lost. It should have been cut down and replanted at the age first named. The ash should have a clean and straight stem, and be cut while yet in rapid growth and full vitality. 
In Englami, the larreh, ash, and pophar, are ripe at tifty to sixty gears, while the oaks phanted among them may continue to grow one bundred to one humberl and tity years, and a second crop of the earlier matur. ing species be matmod anomg the oaks. Mr. Michie maces the maturo age of the elm at eighty to one hundred years.

\section{METFOROLOGICAL INFLUENCES.}

'The intluence of forestion rainfall has been so frequently and exhaustively disemsisel that little of value ean here be added. From ten thou. and observations marle in Parana the mean annual temperature of the forest soil was fonnd to be 210 lower than in the open field, and the mean ammal temperature of the atmosphere of the forest 100 lower fhan in the open tield. Relative moisture was fomm to be 6 per cent. greater than in the open field, a per eent. in summer and 5 in the other seasons. In the mountain regions the difference was greater than at lower elevations.

It is not necessary to assume that forests induce a heavier rainfall, or even to show that the inthence locally the distribution of rain, to prove their beneficence in regulating the moisture avalable for the use of agrienlture. The foliage of forests resists the violence of storms, breaks the force of the lainfall which percolates through the eovering of leaves and moss, and is absorbed by the humus heneath to be given ont by the slow process of retarded evaporation, the surplus fumbing its way to the springs deep in the earth. In an open field the storm beats with unbroken violence upon a suffee impacted and hamdened under the rays of the sun, finis to penetrate the soil. and rushes on in turbid streams down the slopes to swell the bronks and rivers, and instead of refieshing the earth scarifying and wasting it.

The world is fall of examples of once verrant and productive areas which have become burned and blackenerl deserts. The gradual desiceation of the once green and productive islands of the West Inolies, Samta Cruz and Saint Thomas, which has bextl progressive for many years, is the result of the destruction of primitive forests. The little island of Curaçoa, where rich plantations, heautiful villas, and terraced gardens have given place to aridity and resolation becanse of the export of its valuable timber, is a striking illustration of the changes wronght by forest destruction. The entire coast of the Merliterrancan, once the garden of the world, has been hlighted into enmparative har. renuess hy the denudation of the forest areas. A portion of this ter. ritory, the Kanst rexion of sonthern Austria. bondering on the Alriatic, has been the scene of extensive ratforesting work by the Austrian Govermment. ('enturies age) it was covered with magnificent oak forests, and furnished piles and ship-building timber to Vonice during her brilliant matime "ander". So dense was the forest mpon the Istrian coast that a segrimel could traverse it for miles on the branches of tho trees. It was plundered systematically by V'enetian spoilers till the whole region mas refluced te barremess and porerty. For a seope of 4468 LOR - 
miles north of Trieste the soil itself was washed away by the floods after the exportation of timber had been followed by relentless fires, leaving the bare rock in rugged masses as the sole covering of the surface. The work of restoration, commenced nearly twenty years ago, was one of exceeding difficulty. Exposure to sum and rain had exhansted the fertility of any remaining forest humus; the underlying masses of chalk were seamed and honeycombed with cavities requiring a mixture of underlying clay to spront either grass-seed or tree-seed. Yillions of trees were annually supplied by the Government nurseries of Austrian pine, ash, lareh, and other varieties, and year after year the. slow and patient effort has been continued with results that promise the ultimate renovation of a vast area of several humdred thousand trees, though the blasted district is yet a scene of comparative desola tion, requiring millions of treasure and years of patient labor to restore a tithe of its profusion of torest wealth.

The productive (ap)acity of the United States is due not alone to the great fertility of its central areas but, in a large measure, to the amount and reasonable distribution of the rainfall. The lower latitudes, the Southeru States, where high temperatures prevail aud evaporation is greatest, have a rainfill of $4(0,50$, and 60 inches annully, with a liberal distribution throngh the summer months. The lake region and the Ohio basin have less, yet a good supply, suited to more temperate conditions, a lower temperature and less evaporation. Yet the droughts that oceasionally prevail, and which are most severe on the borders of the wooled belt, as in Texas, Kansas, Missomri, and Illinois, should admonish us to avail ourselves of the local benefits of forests in the equalization and conservation of the rainfall actually received.

Some of the States have less than the rule of the Duke of Burgundy requires: "One-third to the hunter, two-thirds to the husbandman." The rule of IVilliam Penn, one acre in wools for five acres cleared for agricultural lands, exclusive of the wooded hills and mountain forests, was not materially less. Ket Vermont, Massachusetts, and Comnecticut in New England have less than a third of the farm lands in forest; New York, 2x per cent.; New Jersey, 24; Pennsylyania, 29; Delaware, 26; Ohio but '2t per cent.; Michigan, 32; Indiaua, 29); Illinois, 16. These are originally wookled States, except a part of Indiana and Inlinois.

The necessity of a carreful and aceurate cultivation and restoration of on forests is now recognized by all. For three-quarters of a century we have been busily engaged in the husiness of lumbering; the time has now come when we must tum on attention to the business of forestry. The gateat wool erop, which nature lavished on on ancestors, has heen so diligently gathered that all our ingenuity will be taxed to contime the necessary smpuly for the glowing wants of a rapilly increasing population. It is to this point that this association should especially turu its attention. It is to this point that I hare directed the work of the Forestry Dirision in the Inited states Department of A grienlture for the derelopment of the forest industry of this country. 


\section{A P P E N D I X.}

\section{THE FORESTS AND THETR MINAGEMENT IN OTILER COUNTRIES.}

[From the report of R. W. Puipss, Esq., Toronto.]

IIANOVER.

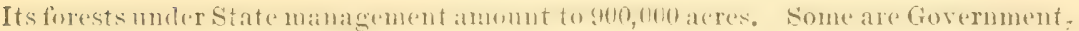
some church, some belong to municipalities or communes. Government manages the forests by ofticers appointed, while the community pay four cents per aero towarls the pay of the officers. The method appears to be that of giving the owners as much wood, pasture, or litter for manure as their original right to the forest entitled them to; but to give it at the hands of Government officials. If the forest is of sufficient extent to employ a sperial ofticer, the commume, insteal of the four cents, are charged his pay and allowances, as well as other working charges.

The Government forests are about 600,000 acres of the above, and the cost of work-

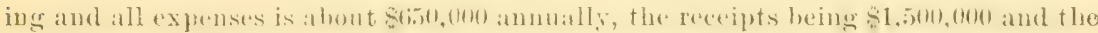

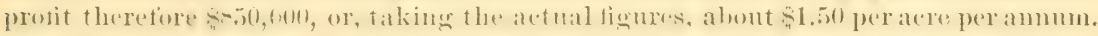
This, of conrse, takes no account of the value of the laud, or what it might rent or sell for if cleared.

Hanover is a province of Prussia. The head oflice is therefore in Berlin. The forest establislument of Hanover consists of 1 forest director and over-forest master, who is also a conncillor; 20 forest-masters in charge of cireles or divisions, forming also a board of mauagement in all forest matters; 112 over-foresters in charge of forest districts (retier), averaging beren or eight thonsand acres each; fo3 foresters who assist the over-foresters, and bave charge of portions of a district; 343 overseers, under-foresters, \&e., emplojed in watching and protecting the forest, and supervising the work which is executed by hired weekly or daily labor, or on contract under supervision of the fixed establishments. A cash-keeper is attached to each over-foresters. who receives and disburses all moneys ont of the forest cash chest, with which the over-forester has nothing to do, although his accounts should, of course, tally with those of the cash-keeper. For payment of laborers, Sce, he gives orders on the cashkeeper, whose books are examined by the forest-master in charge of the division, and accounts reudered to the head office in Hanover and thence to Berlin.

All the forests have been surveyed, valned, and divided iuto blocks in this manner: Besirles those already enumerated, there is, for the sole purpose of measuriug, valning, and framing working plans for the forest, a superintendent, draughtsman, and clerks, gemerally practical foresters, and a staff of surveyors and forest valuators, who are generally caudidates for the position of over-forester.

When a forest was about to be taken in hand and worked systematically, a surveyor and valuator were dispatched to the spot, the former working under the directions of the latter, who placed himself in communication with the local forest officer and the inbabitants interested, and obtained from them all the information in his power. The surveyor first survejed the whole district, then the different divisious as pointeri out by the valuator, who defined them according to the description of the timberstancling, and any conditions afiecting the nature of the trees to be grown in future. 
While the surveyor did this, the raluator valued the trees, formed a register of rights with a riew to commutation, considered the best plan of working the forest, the roads, in fact, all which enabled him to form a plan for the head office, and a subordinate plan to be handed over to the execntive officer as his "standing orders."

The valuator and surveyor return to headquarters, and prepare the maps and plans, which are submitted to the board of forest-masters, the forest-director, and other councillors of the finance department, who are thus prepared to listeu to any objections made by communities or individuals, which are very rarely made now, as the people have learned that the action of the officers is not adverse to their interests, and are willing to allow them to settle matters.

The executive officer has thus in his hauds mans showing each division of the forest tract in his charge, and instructions-the quantity to be felled yearly, the extent to be planted, the state in which the forest should be ten, twenty, or a hundred years after the plans were made, all calculated-so that the over-forester has only to carry out the instructions given him, allowance being made for unavoidable difficultiesfailure of seed, occurrence of storms, and the like.

The forest-masters have no executive work, but control four to six over-foresters, of whose labors they make frequent reports to the director (both in forest and offico work). The over-foresters give aunual reports of operations. They spend most of their time in the forest, supervising the felling: planting, sowing, thinning, carting, and selling of timber. The laying down of roads is done by a forest officer, but the actual work is carried ont by the local officer, who has also much office work, giving grazing licenses, etc., and preparations of returus; but his work is out of doors contpared to that of the forest-master, who has more office work, comparing operations and rates in the districts, collecting statistics, settling disputes, and as a member of the forest committee, revising working plans.

The main object aimed at in any scientific forestry is to convert the uatural forest, consisting of trees, young and old, good and bad, too thick and too thin, into blocks of trees of the better description, of the same age, and capable of being worked-that is, thinned out, felled, and reproduced, or replanted, in succession, a block being takeu in hand each year. In carrying ont such a system, considerations must be attended to, such as the relation of the block to the whole forest system; the needs of the people in timber, firewood, leaves for manure, and pasturage; the soil, the situation as regards winds (which must be attended to in felling to lessen damage), and precantions against insects, fire, trespass, or theft.

The plans need revising every twenty years, though it is marvelons to notice to what an extent the original scheme has generally answered.

After a forest has (to give some idea of management), by thinning, planting, and so forth, been gradually got into perfect order as describerl, the system of natural repro. duction forms great part of the German method. It is as follows:

The rotation and periods are fixed in the working plan. For beech "lochwald" it is in Hanover one hundred and twenty years, divided into six periods of twenty years each; that is to say, when the forest has been brought into order there should be nearly equal areas under crop of trees in each of the six periods-that is, from one yea * to twenty; from twenty years to forty, and so on. When a block arrives in the las period, felling is commenced by what is ealled a preparatory elearing, followed by a "cleariug for light" in the first jear after seel has fallen (the beech seeds every fourth or fifth 'year), with the object of, (1), preparing the ground for the seed; (2), allowing it to germinate; (3), affording light to the young seedlings. If there is a good seed-year and sufficient rain, the ground shonld bo covered with seed. lings in two or three years after the first clearing; but it is better generally to wait for a second seed-year, and aid nature by hand-sowing, transplanting from patehes of many to the barer spots, and turning up the turf to give the seeds a better chauce of germinating.

When the ground is well covered the old trees are felled and carefuly removed, so 
as to do as little damage as possible to the new crop, and the block recommences life, so to speak, nothing further being done till the first thimning. The time allowed between the first and final clearings is from eight to fifteen years. But in many provinces they do away with this system, and remove the old trees so gradually that there can lardly be said to be any cleariug at all, the new crop of trees being well advanced bofore the last of the old trees is removed.

In these forests can be seen all the periods of growth-nurseries and schools for seedlings, which are trausferred thither, at the age of two to four years, from the seenl beds, and are pruned and transplanted as often as seems required till finally planted ont, sometimes not till twelve or fourteen years old. There are many methods of planting adopted here. 'The steeprest and most rocky sides of the hills aro covered with forests, which have been created by the labors of the forest department. In many such places, where even the few handfuls of soil placed round the young tree Lad to be carried some distance, it is not contended that the first plantations will yield a pecuniary profit, hut the improvement in elimate bs the retention of the moisture and reclamation of large tracts formerly barren and unprodnctive is takon into accouvt; besides which the dropping of leaves and needles from the trees will cre long create a soil and regetation, and insure the suceess of plantations in future jears and consequent surplus.

PIIUSSIA.

Prussia biss $20,000,000$ of acres of forests, $10,000,000$ of which are private, and the remainder, with which we have more to do, state, commercial, and ecclesiastical. Of these the income is $\$ 14,000,000$, and the expenses $\$ 7,500,000$, leaving $\$ 6,500,000$ clear. This will not show much, in fact not more than 65 cents per acre, but there are other retums of more than mere yearly revenne importance. When it is consiclered that this result is arrived at withont trenching on the capital or stock of timber in the forests which, on the contrary, is being inereased and improved in every province of the kingdom, and that the indirect value to the people of many forest privileges, which they exercise free of charge, must be very great, not to mention the benefit to all in the shape of public recreation grounds and an improved climate, some idea may be arrived at of the enormons value and benefit such a system of state forests must confer on Prussia.

The forests, as already stated concerving Hanorer, form part of the finance department, and are presided over by an overland-forest-master and ministerial director. aided by a revemue councillor and joint ministerial director, and a numerous council or board.

There are two forest academies, one near Berlin and one in Hanover. The overland-forest-master is curator of the academies, and at the head of each is an overforest-master, who is aidled by a uumerous staff of professors and assistant professors.

There are twelve provinces in Prussia, divider iuto thirty circles, and to each an over-forest-master, who is appointed to represent the forest department in the council of local ad" inistration, and is aided by comncillors and by the forest-masters as a

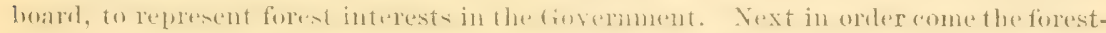
masters, numbering 108, in charge of divisions with an arerage area of 60,000 acres, and then the executive officers, 706 over-foresters, to each of whom is 7,000 acres, and to each of whom is attached a cash-keeper, aud 3,646 foresters, or orerseers with ranges of 1,000 to 3,000 acres.

At the acarleny near Berlin are seven professors with assistants. There is an experimental garden attuched, with an over-forester in charge of the technical portion, and professors for the meteorological, zoological, and ehemical sections. The number of students arerages sixty-five. The varied apparatus ineludes a building where the serd is dried and separated from the cones, large seed-beds of spruce, fir, and willow, full opportunities of transplanting seedlings. and exauples of every kind of trees for botanical study. 
There is here a museum, rich in specimens of all sorts of birds, animals, and insects found in the forests. In cases where the animal or insect does damage to trees, specimens of the branch, bark, leaf, or cone, in a healthy state, and after being attacked, are exhibited close to each, so that the students can see at a glance the nature of the damage and connect it with the animal which canses it. Thus we have squirrels, rats, beavers, mice, set up gnawing the barks, grubbing at the roots, \&c. Insects are shown in the several stages of their existence-larvæ, chrysalis, caterpillar, moth, with their ramifications in the stem or branches of the tree. These, with specimen blocks of almost all descriptions of timber, form a most instructive collection. There is a forest district attached, remarkable for the growth of Scoteh fir and spruce on a poor sandy soil, and in spite of repeated attacks by insects.

Nothing is more remarkable than the extent of study recuired from forest caudidates, and the number of pears they are content to spend in studying or waiting an appointment. The would-be over-forester, which is the lowest of the gazetted appointments, must pass certain terms at a Government school, a year in a district with an over-forester, an examination as forest-pupil, two years at a forest academy, an $\mathrm{ex}$ amination in scientific forestry and land surveying. He is then a forest-candidate. Then two years' practical study, nine months of it doing duty as an actual forester; then another examination. He is now an over-forester capdidate. The first examination tests his theory; the second his practice. Then he will be occasionally employed in the academies, or in eharge of a district, only then getting allowances. After five years of this he may look for steady employment.

Thus five years withont pay are given in study; five in probation with but meager pay when employed, and the time is often longer, before regularly installed. Yet so great is the desire for Government-especially forest-service, that there are numerous candidates.

The qualifications for armission into the subordinate grades-forester, sub-forester, overseer-have a military tendency. Candidates, after two years in the forest, enter a jager battalion, and biud themselves for twelve years' service. After three years they obtain leare, and are employed in the forest as huntsmen or gamekeepers. After eight years they must have passed the forester's test, which consists in six months' charge of a district, and an examination. At the end of twelve years they are discharged with a certificate entitling them to employment in the forest establishments. The appointments are much sought after, and in 1867 there were two hundred and twenty-one applicants for one hundred and forty-five vacancies; but many are absorled by communal and private forests.

In some provinces the Prussian Government has certain rights concerning the management of even private forests; in others none.

While on the subject of Prussia, it may be woll here to insert some extracts from a letter received from Baron Von Steuben, a Prussian noblemen, now royal chief forester of the German Empire, by the Forestry Congress, at Cincinuati, in April of last. year. He remarks:

"There can be no doubt that every country requires a certain quantity of wellstocked woods, not ouly to supply the demands for building material and fuel, but more especially to secure suitable meteorological couditions, to preserve the fertility of the soil, and out of sanitary considerations. The ratio of the minimum quantity and judicious local distribution of the indispensable forest to the aggregate area cannot be expressed by a universal rule, but the same can ouly be approximated by scientific investigation. Above all things, it is essential to prevent forest destruction where such would iujuriously aftect the fertility of the soil. It is important, then, to preserve and to cultivate judiciously those forests which stand at the head-waters and on the banks of the larger streams, because, through their indiscriminate dostruction, fluctuations in the stage of water, sand-bars, and inuudations of arable laucls are occasioned. It appears also necessary to preserve and properly to eultivate 
woods in quicksands, or the summits and ridges, as well as on the steep sides of mountains, along the sea-coasts, and other exposed localities.

"In Germany, aud especially in my more narrow-bounded Fatherland, Prussia, it is regarded as of the greatest importance, not only to preserve the forests already there, but to extend them as much as possible.

"In the national appropriation bill large sums are set apart for the purehase of such lands as are unfit for eultivation, and for utilizing the same by planting trees.

"With reference to forosts owned by private individuals, they are not restrained in the nse of their forestis, and may, acomding to theirown judgment, wear the same and till the soil, in short, do what they like, and yet there may be certain restrictions placed on the free use of the same as soon as danger to the commou welfare is feared; these restrictions are prescribed by the law of July 5, 1875, relative to forest protection.

"This law is applicable in cases-

"1. Where, by reason of the sandy nature of the soil, adjoining lauds, or public grounds, natural or artificial courses, are in danger of being covered with sand.

"2. Where, through the washing away of the soil, or through the formation of casades in open places on the ridges of hills and on hillsides, the arable lands, streets, or huildings lying below are in danger of heing covered with earth or stone, or of being tooded; or the lands or publie gromuls or huldings lying alove are in danger of slivling.

"3. Where. through the destruction of the forests along the banks of canals or natzural streams, riparian lands are in langer of caving, or buildings hitherto protected by the woods are in danger of iceflows.

"4. Where, through the destruction of forests, rivers are in danger of a diminution of the stage of the water.

"5. Where, through the destruction of forests in open places and near the lakes, zeighboring fields are seriously exposed to the detrimental influevces of winds.

"In the cases abore mentioned, which have been copied verbatim from the statute book, the manner of use as well as the culture of forests may be legally ordered, in order to prevent those dangers where the dangers to be arerted are considerably in excess of the damages which would result to the owner by reason of the restrictions."

SAXONY.

The stite forests are nearly 400,000 acres, worked at an expense of $\$ 500,000$, receivIng $\$ 1,750,000$, leaving a elear rental of $\$ 3$ per acre. The expenditure is planting, Araining, roads, improvement of inferior woods, folling, trausport, killing insects, sc. About 5,000 acres are planted jearly, at an average cost of $\$ 7.50$ per acre.

The fixed establishment is 1 inspector, 15 over-forest-masters, 120 district foresters, 16 cash-keepers, 13 engineers, 27 foresters, and 83 sub-foresters.

There is a forest academy at Tharand, with a separate stati of professors.

The system of planting now principally experimented on is much the same as that previously described, the young trees being several feet high before the old trees are all removed. One operation is noticeable. It was decided to convert a mixed hardwond forest, patchy and irregular, with impoverished soil, in 1820, into a coniferous forest, and maps were drawn showing what it would be in eighty years. Private intersecting lands have been bought up, and by 1900 the ideal chart will be actual. Already, in place of a straggling wood, irregularly covered with timber trees of iuferior growth, we have now a compact close forest, regularly wooded in sectious of different ages, principally spruce and Scoteh fir, but containing also tiue oak, ash, and beech, with straight and clean stems. In many cases the young oaks have been left where pines were planted, and the introduction of the latter has lad a wonderfully good effect on the oaks.

All private rights were abolished and compensated in these forests by a bill passed in 1832 . 


\section{BAVARIA.}

The state forests are $3,000,000$ acres. They return, after paying all expenses, abont $\$ 1.50$ per acre per annum. About 30,000 acres are planted or sown annually, taking 35, 0e:10,010 plants and 1, (1001,010 pounds seed. Persons found guilty of breach of forest rules have been punished by enforced labor in the woods. Private forest rights are being bought up by the Government.

The system of management is much the same as that previously described. There is a forest academy at Aschaffeuburg, with one hundred and sixty-five students.

It will be interesting to notice the injury and process of repair in the fine forests of the Spessart in Bararia. The deterioration was eaused by felling the forest trees as soon as, or before, they were mature, the imporerishment of the soil by tie removal of leaves and litter, and the allowing dense underwood to grow unchecked. Inferior trees got the upper hand and prevented the growth of good, while they drained the already impoverished soil and gare uothing in returu. Early in the present century the matter attracted attention, and every means bave since been adopted to grom oaks, beech, and conifere. The result is, though not yet equal to the muiformity of other forests, nowhere can one find finer elumps and individnal trees. Inferior trees will soon be rare in the whole forest. In remote portions where the humus had not been destrojed, the growth of beech and oak is truly magnificent, tracts of 120-year old beech and 300 -year old oaks leing common, the latter with clear trunks rumning up to a hundrerl feet high. When we compare these with other portions where the crippled and.stunted appearance of the trees shows the effect of unregulated grazing and loss of litter, burning of the decared wood, and forest theft and mischief, or the soil and regetation, the result is marked. The cirenmstances, says the Indian commissioner, are analogons with what has gone on in India for centuries, and is still more or less permitted. The vast extent of forests, which once clothed the hillsides and extended far ont on the plains, and the luxmriant growth of the tropics, have hitherto, or until the last two years, preveuted the gradual deterioration of our forests being marker or felt, but the sulject has now attracted attention, and none too soon. . If any have doubts in the matter, let them visit tlre Spessart, study the history of its forests, and judge for themselves.

The for sts are shaxply protected by lam, the average number of prosecutions aunually being thirt y per thousaud acres. The crimes are mischief to wood, pasture, grass: straw, aud miscellaneons.

\section{AUSTRIA.}

Scientifie forestry is not so far adranced as in Germany, but officials are busily introducing a reorganization, by means of which, there is no doubt, it will soon be on a par with other states.

The state forests hare been largely sold to meet state necessities, but there still remain nearly 2,000,000 productive acres, which yield, however, after expenses are paid. little over twenty-tive ceuts per acre.

The existing establishments of forestry are not uniform, but there are about 1,200 employés, of whom 22 are forest masters. Some of these have almost sinecures, while others have six times too much to do, and it is the same with those in the subordinate ranks. The forest academy is at Mariabrum, near Vienna. There are about 35 students.

The collections are fine, possessing specimens of all instruments and appliances made use of in felling, squaring, sawing, cartiug, and preparing timber, models of saw-mills and machinery of all descriptions, plans of river beds improved and embanked for floating, sluices of all sorts, dams and piers for directing rafts in their course and catching fre-wood, models of rafts, and specimens of home and foreign timber of all kinds. The damage done by animals and insects is also exhibited here comprehensively. There is also a forest garden attached to the academy for the instruction of the studeuts. 
'The stafi' of the academy comsists of the clirector, 1:3 jrofesines and assistant professors, with suhordinates in the acenunt oficese lahouatory, de. There is also a forest school at Bruhl, for training youmermen (of whom were there) as pratical foresters,

The greater number of those trained here are intended for private and not for Gov-

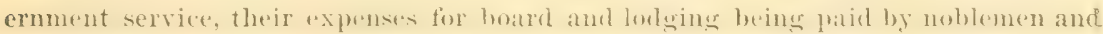
large proprietors, from whose estates they come and to whom they return as forest ofticers and workmen. 'The state maintains the schools and pay's the professors' salaries, and there are no extra fees. This canuot fail to assist tho intelligent management of the private forests of the empire, which are very extensive. The absence of numerous candidates for the Government forest service and the preference for private employment are noteworthy when compared with the opposite state of things in Prus. sia. The irregular promotion, lack of systen, and low salaries in the Austrian forest service are the explauation.

'The Austriau crown forests have been neglected; they are patchy, with a low and decreasing yield per acre. There has been till now no attempt at rotation of blocks or working in periorls. As is found in India, a glauce at the outskirts of the forest would lead one to suppose it fairly stocked with timber, but a more careful inspection proves that this is not the case, and that only in the valless and more remote portions, where the soil is particularly good and the ax has not. been so frequent in its inroads, is there a fair and regular crop.

Herr Schuppitch, the present director, is trying hard to change matters, and is changing the hardwood crop, which has exhausted the soil for that elass, with pine growths, which, besides, grow ruicker and pay better. Ho is also dividing into blocks and periods, aud plauting up many bare or ill-covered tracts, where natural reproduction is impossible oring to the absence of standard trees.

GRAND DUCHY OE BADFN.

We shall now notice a private forest, that of the Prince of Furstenburgh, in the Black Forest. The receipts aud expeuditures are not obtainable, as are the public oues, but we are informed that the forests are econumically worked, and that the liberal smms expended on road-uaking, fitting rivers for floating, honsing foresters, \&c., were well repaid by the facilities secured and coutentment and zeal of the employés. In the case of this, as of other private forests, it is evident that a private iudividual is not burlened with consideratious of policy and public good as in a state. The forests are, therefore, worked with the best profit compatible with their retentiou as capital.

There are about 72,000 acres, in charge of eighteen foresters aud over-foresters, who of course have many subordiuates. The method employed is the slow felling and con-

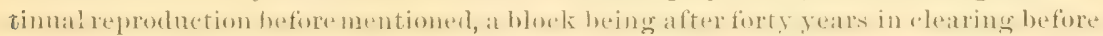
all the old are replaced by new trees. Attention and intelligence are necessary, for the seed will not grow nor the seedlings flonrish without enough light, and the forest officer must watch that they gret it; and again much greater care is needod in felling and hauling a ray when the trees are smromuded by lofty saplings and young trees thau when the seedlings of the next crop are not more than a foot or two high. In this the axmen of the Black Forest are adepts, and the damage very slight to what it would be in other hands.

It may be useful to describe their manner of bringing timber down the rivers. It camnot here be done when the stream is in flood; in fact, the less water in it the better so long as sufficient is stored up above to float the rafts. Reservoirs are made, and the water poured into the river bed when the raft is ready. The streams aro often small, of only fifteen or twenty feet in width, and have to be prepared for floating, by being cleared of any large rocks or bowlders, aud "sleepered," if we may use the expression, by pieces of wood timly fixed in the bed of the stream every fow yards. These prevent the formation of loles in the bed, and serve for the raft to slide on if it touches the bottom. The first impression of the Indian commissioner when he sass 
the tloat, composed of stems from twenty to sixty feet in length tied together with withes at the ends and lying zigzar in the bed of a mountain stream, up and down which they extended sixteen hundred feet, was that it was simply impossible they ever could be floated down the stream, with all its windings, and over the locks and rocks which occurred pretty frequently. It contained eight hundred and eighty stems, eight or ten of which abreast formed as it were a link in the raft. There were thirty links, not fastened laterally, but only at both ends to the next liuk. The breadth is greatest about two-thirds from the prow, which is narrow and consists of only three stems abreast, with, in front of all, a piece formed of old wood and raised out of water like the bow of a whale-boat, so as to lead the raft, and the largest and heaviest stems placed in the broadest part and towards the stern or hinder part, which does not taper at all. There are two or three brakes, by which the speed is slacked or the ratt stopped if needed. When all is ready, the water from above is let loose, and the raft, perhaps not now lying in more than a foot of water, begins to. float a little but is not let go till two-thirds of the water is passed, as it is a curious fact that when let go, if there is much descent, it travels faster than the water, and has to be stopped to let the water get ahead again. The raft has eight or ten men and boys, one or two of whom stand by the master at the chief brake, on which the safety of all depends.

When let go it is exceedingly curious to see the forward part dart off at the rate of five miles an hour, and the several links which have been lying zigzag and perhaps ligh and dry uncoil themselves and follow in its wake till the whole dashes along at great speed and apparently uncontrolled. Accidents are rare, as they are well trained (lads of six or eight can be seen going (lown in miniature floats); but for one not accustomed to it, it is nearly impossible to stay on the raft at all, as it literally springs out of water on touching a rock, dashes round a rapid turn, or jumps a weir with a fall of several feet. Forty or fifty miles can be got over in a day if stoppages to let the water ahead are not too frequent or the stream is not swolleu by rains.

\section{REMARKS ON GERMANY.}

The Indian commissioner proceeds to remark on the German system of foresty. Perhaps it will be here admissible that I make one msself. Let me say that, when we consider the immense extent and rapid growth of forests in India, the vast amount in. Government hands, and yet find that they are so rapidly deteriorating as to necessitate the dispatch of commissioners to Europe to learn the methods of preserving the forest, it is likely that Canada has just as much reason to bestir horself in the matter. Let us notice also, by some of the valuable tables Captain Walker has furuished, that in Germany and Prussia alone there are nearly 250,000,000 of acres of forests. We will well have alrealy understood, by the foregoing pages, how different the great mass of these forests, with their great reserves of growing and well cared for trees, planned and prepared for many years, so that the forest can be depended on to give its reguIar and ammal yield of valuable timber in perpetuity, are from our Canadian reserves, which are cut withont regard to the future, and are fiast disappearing before the combined assault of the settler and the lumberman. On asking where are we to look for a model or precedent on which to work, he replies:

"To Germany, where the management of forests by the state has been carried ou for hundreds of years. Not the mere planting of a few hundred acres here, or reserving a few thousaud acres there, but a general system of forest management, commencing by a careful survey, stock-taking, definition and commutation of all rights aud servitudes, careful experiments in the rate of growth, the best soil for each description of tree; in fact in every branch of the subject, and resulting in what we find to-day, ßundreds of thonsauds of acres mapped, divided into periods and blocks, and worked to the best advantage both with regard to present and future, and the annual sield of which now, and for many years to come, is known and fixed to within a fer hunslred cubic feet."

"The great difference," says the commissioner, "in elimate and local conditions be- 
treen India and Germany would, doubtless, necessitate important modifications; but I can see no reason why the broad principles of organization and forest mauagemeut should not be applied with suecess to our Indian forests, that is, gralually feeling our War as regards the best mode for the forest and the wishes and interests of the people and the state."

I would here remark that this is still more applicable to Cauada, as our elimate presents no difference of moment.

"I do not think," he continues, "that we have much to. learn from the Germaus with regard to the planting and rearing of young trees; but it is with regard to the best method of managing groups or plantations that I consider we may with advautage take a leaf out of their book. For instance, I would certainly introduce, in an experimental mauner and on a vory small scale, their system of rotation, clearing, and periods, and endeavor to bring forward a second crop before the first is off the ground, encourage the growth of the het ter deseriptions, and ketp down the least valu:hle, su as gratually to arrive at errompsof trees of the same age, description, amd class, moleventually at blocks worked in rotation, and containing always a sulficient stock of crop coming on to meet the requirements of future years. To arrive at all this the most careful observations and experiments will have to be made as to the rate of growth and yield per acre of each deseription of forest, the couditions under which trees grow best and form the most timber, some requiring elose and some open planting, some nurses and some not; some, like the oak, requiring a great deal of light, while some, like the beech, do best for mauy years in tho shade. All these points, and many wore, demand attention, and till they are settled we shall be merely groping in the dark. In fact, I think it mav be taken for granted that all we will do in the way of forestry in the Madras Presideney, during the present century at least, will, after all, be but experimentalizing, which fact, however, need in no way delay the demarkation, survey, aud settlement of the forests.'

It may be said here that, if it be necessary to commence at once in Iudia, it is probably more necessary in Canala, where the process of growth is so much less rapid.

Concerning the capabilities of German foresters, the Captain says :

"An over-forester, and eren many of the foresters and overseers, can tell the name, local and botanical, of auy tree, shrub, and plant, classify it, aud state its uses; name and classify every beetle and insect in the forest, and know whether they are harmless or destructive to trees, in what shape they do damage, and what are the best known preventive measures; inform you of the nature of the soil, and to what period the formation belougs; what trees will grow best, and why. All this is known thoroughly, theoretically aud practically.

"Then as to the district, the exact yield, rate of growth, and anmul increase in ralue of each block is thoroughly known and can be put down in figures at each moment by the over-forester, who can tell at the commencement of cach year how much timber he is going to cut aud.sell, aud from what parts of the forest it is to come, how many acres have to be partially cleared for natural reproduetion. how many to be planted, sown, thinner, or planted up. The mere details of all this are left, as a rule, entirely to the subordinates, who thoroughly understand them.

"The forest-masters in charge of divisions possess not only the theoretical and scientitic knowledge acquired in the forest academy, and the prictical experience gained while they were over-foresters in charge of a ristrict, but the more extenderl knowledge and wider views from their larger field for observation aud comparisou of causes aud results. They are then qualilied to decide most points, revise working plans, and supervise operations generally whilst settling complaints and complications in comnection with the forest administration, advising the local head of the department, and compiling valuable reports and statistical information."

THIE BRITISH ISIES.

There are many forests, both Cromn and prisate, in the British Islands, conceruing which, as thes appear to be managed on different systems, I shall merely state such 
points as seem to lave some bearing on possible operations in Canada, or may show the progress made in late years in planting and foresting operations.

In the Ner Forest, Hampshire, containing 91,000 acres, much has been planted with Scotch fir and larch in 1853, and with oak in 1857. What is noticeable is that the first, plauted as nurses, are planted here so much before the others (both are elsewhere frequently planted at once). It is done to establish the nurses, and give shelter from the entting winds prevalent here. They transplant here from the first nursers to another-the last one noar the nltimate destination of the trees.

The Dean Forest, in Gloncestershire, las 22,000 acres in all. The commissioner visited twelve plautations here, rauging from 1844 to the present year. Nurses and hardwood are put out together.

In Scothand, the mursedies of Lamson \& Sons, near Edinburgh, are noticen. Ther contain 270 acres. There were $30,000,000$ conifere seedlings in the beds. The pims. pinaster is largely used for planting on light sundy soils near the sea.

Before sowing or forming the mursery bed the land is trenched to fourteen inches. and a crop of potatoes taken off to clean it. In the following spring the seed beds are laid out, and the upper soil caretully prepared to suit the nature of the trees which are to be sown. Most of the coniferw prefer a light dry soll with a considerable proportion of sand, aud this has the advantage tinat the seedlings are easily shaken out. and freed from each other for transplanting. In the case of Scotch fir and larch, the seed is sown in Mar or Jume, and left in the seed bed for two seasons. The seedlinge are then planted out in lines fourteen inches apart and three inches between each plant, are left thus for sometimes two years, and then planted ont for good. It is thought better, if the frost can be prevented from killing the seedlings, to sow in April, and transplant one year after, or eren the same antumu, as soou as the leaf bud is hard. The spruce requires two years in the seed beds, as its growth is slower than that of lareh. The pinns pincster, restriaca, and lavicio are sown in May or June, and transplanted the same antunu into rows six iuches apart, the plants close together. Hence they are transplanted the following autumu, into rows fourteen inches apart, where they are left one or two years before being planterl out. It is considered an object to shorten tap-roo's and encourage laterals. (This last idea, it will be noticed, may assist the tree; but not that main object of forest preservation, the conuection between the upper and lower strata.)

The Earl of Seafield's wools, in Strathsper, give an instance of the rapidity with which planting is going on in Scotland. There 60,000 acres, of which half are in timber, yet so youmg that the commissioner saw little large wood ready to cut, but plenty of thinnings. The overseer intends gradually to plant the whole, so that, in course of time, a thousand aeres could be cut ammally and a thousand planted ont, which could not, it is said, fail to bring in a large revenue without trenehing on the capital of timber. Three liues of Scoth fir the commissioner saw lifted aud tied in bundles for planting ont. This was done expeditionsly by the fire-pronged fork, two men digging out the youngr trees, which are then lifted by women, the earth shaken off, and tied in bundles for plauting. This list will give some idea of the progress on only one estate: Duthil Hill, z00 acres, planted six years; Deshar, 1,100 acres, withiu seven Jears; Slnemore, 600 acres, five years; Revock, z00 acres, four Jears; Bengalupin, 1,200 acres, six years; Advie, 300 acres, one Jear.

A point here presents itself which, thoigh it seens vague and not accorling with Canadian experience, it might be well to examine and find the meaning of. The Strathspey overseer consider's that "in Strathspes, at least, the land shonld be left barren and untonched, after it is cleared of trees, until the natural herbage, whether heather, grass, or moss, which existed before tho trees grew, recovers; and that if planted before this takes place, failure will result."

It may be remarked that oak is now little planted here, its use for ship-building heing much less than formerly; while even for backing for iron-clads it is abandoner in favor of teak, which has not the injurious effect on the iron produced by the con- 
fact of oak. Scotch fir and lareh are mneh planted, and are rapid in uatural production. Whenever the natural vegetation has sprung up in places formerly covered with coniferous trees, the seeds germinate. This is then protected by wire fences with great success. In a large tract of self-sown forest in the Grantown district, inclosed six years ago, the Scoteh tirs average six feet high, while individual trees run up to ten feet.

Wire fence, tarred, three feot eight inches high, can be constructed for seventeen cents per yard, posts and all, and is much used. After ten years, or when the trees have grown out of harm's way, pasture is sometimes let. Inclosed plantations for this purpose command 2.s. $6 d$. per acre, while ordinary hill side pasture gets but $6 d$.

The Earl of Mansfield's woods, in Perthshire. These are about 10,000 acres. Planting is going on constantly. There are nine district foresters and a large staft of woodmen. A large plantation of Douglas pine is mentioned as doing remarkably well. They were planted in pits fifteen feet apart, fifteen inches square, and ten inches deep, with lareh and Scoteh fir unrses at four foet apart. The pines average twenty-five feet in height. The nurses are being removed. The overseer disagrees with the strathspey statement as to leaving the land hare, and comsilers that it is only the insects (the beofle) which hinder the growth of sedlings on land cheared of conifers. He succeeds well by excluding cattle for one year, lotting the grass, \&c., grow, then burning it when dry, and planting out.

The Duke of Athol's woods, in Perthshire, comprise 10,000 acres, and were commenced in 1728, principally with larch, which has done well in places, but is now undergoing the substatution of Scotch fir, which pays better. Oak coppice cut at intervals of twenty years yields $\$ 60$ per acre.

\section{FORESTS OF LUSS AND THE HARZ.}

Another gentleman, M. Gustar Mann, Conservator of Forests in Beugal, has proceederl to (xermany for the sime purpose as Calptain Walker, and gives some further important information relative to the German forests.

In the plain of Forth fermany the seoteh fir is the prineipal forest tres, and hetter suited for deep, loose, sauly, than for heavy loaming soil.

The great "Luneberg Heath" is mentioned as having been covered with wood, but the indifierence of the inhabitants to the existence of forestis, originating in the common belief that they will continue to exist no matter how recklessly treated, the desire of the villagers to get grazing eround for their eattlo by burnine the forests, the indiscriminate usage of the wool and method of felling iu vogue, havedestroyed hundreds. of miles of forest, and have left the greater part of the Luneberg Heath barren, covered almost exclusively with heather, and of little use to any one. Now the evils are seen, and with a view of restoring these forests large sums of money and much skill and labor are being expended.

I will yuote here a short descript ron of the method used in planting the seoteh fir in such localities. 'The land is first plowed, after which a man procecds along the bed making holes at distances three fect by five, with a wedge sparle (one ditite straight, made ail of wood except the edge, which is shod some inches high with iron, and is two inches thick at the top of the blarle). This he forces into the ground, withdraws it, and passes on, while two women follow him, who plant by holding the seedling against the side of the hole, while with one foot they press the oppresite anth against the plant. The material for planting ennsists of one-yeat old seedlings of Scoteh fir, and occasionally a two-year old seedling of spruce, which are raised in the ordinary way by sowing in furrows. The Scotch fir requires more light and air thau auy other, and does not thrive at all in the shade of other forest trees. For the same reason natural reproduction (in forests) is very difficult aud not attempted here. As a tree affording some shade to other trees which require it, the Scotch fir is well suited. If sown or planted very close, early attention to thinning ont also is necessary, as plants early stunted never fully recover their strength. The soil not being rich, the trees 
are not allowed to grow older than sixty to eighty years, this being the age at which the comparative yield of wood is best. Spruce is planted in small numbers with the Scotch fir, and even where the soil is not good enough for it to grow up into large trees with the fir it becomes beneficial by the cover of its dense foliage, which facilitates decomposition of the soil and keeps it moister and cooler than the fir alone conld do.

It will, perhaps, be as well here to give Mr. Maun's very lucid description of beech cnlture:

Seed beds for beech are prepared in the ordinary way, aud the seed is sown in antumu as well as in spring. If the former time is preferred, care has to be taken that the seed does not germinate too early, so as to be exposed to spring frosts. This is prevented by covering over the beds after the surface gets slightly frozen, and by removing the covering in spring so late that the young seedlings bave nothing more to fear from frost. If sown in spring, the seed has to be carefully stowed during the winter. Steaming, as well as excessive Arying, must be guarded against. The first is avoided by turning over the seed or even keeping it spread out; the second by slightly watering it and turning it over afterwards, so as to distribute the moisture equally. A cool, moist room on the ground floor is preferable to a warm and dry one.

From the seed beds the plants are either removed at once into the forest, or iuto other nurseries for transplanting and keeping until they reach a height of thee or four feet. If they are to be planted in open ground, withont the protection of old trees. they are sometimes kept in the nursery until they reach a height of ten or twelve feet, which however is a very expensive measure. In this care is taken that the young shoots are not removed from the stem, as the bark of the beech is very easily burnt by the sun and otherwise apt to be damaged by the weather. Unnecessary exposure of the roots of the young beech is carefully avoided, as they are very sensitive, and demand special care duriug the removal of the plants. Where it can be done some of the soil is left on the roots for the same reason.

Ordinarily the beech forest trees get re-established by natural production, $i$. $e$, the shedding of seed from old trees. When the beech gets mixed with other kinds, as in the coppice with staudard, its regeneration is furthered or checked according to circumstances, but planting is seldom resorted to.

In the pure, high forests of beech the natural reproduction is brought about by gradual and well-considered fellings, which tend to affect this as completely as possible. In hilly or mountainous localities fellings are commenced at the top of the hill. These fellings take place when the trees have reached maturity, and are three to four in number, and distingnished according to the immediate eftect they are intenderl to. have on the forest.

The first felling, called in Germany the preparatory eutting, is intended to facil. tate the decomposition of the dry leaves and branches which cover the surface, and thus prepare it for the reception of the seed, which latter, without this precaution, frequently germinates withont being able to penetrate with its roots the comparatively hard and leathery leaves lying on the surface, and often dies in consequence, while weeds and scrub easily get up in it and cover the surface soon, thus adding to the dificulties to be overcome by the young plants. It is commenced several years before the inteuded regeneration and carried ont gradually; but where the air and light thus admitted are not sufficieut to render the surface fit for the reception of the seed, a timely permission to villagers to remove some of the tead leaves is resorted to. Besides the preparing of the soil, this opening out of the forest induces the tree to flower and bear seed more frequently than when standing very close.

The second felling-the so-called seed-cutting-is carried out as soon as the bearing of seed becomes probable, which can be judged of beforehand by the appearance and shape of the buds during the preceding winter. An abundant seed-bearing season generally occurs with the seed after longer or shorter intervals, but sufficient seed for the regeneration of the forest may be reckoned on every second or third year. Precantion. 
is used not to remove too many trees at once, as in case of the flowers being destroyed by spring frosts or other (anstis, the restockiug of the gromml with young plants does not succeed. Too much light would dry up the surface of the soil, and induce the weels to overrun the ground, hoth rircumstauces sexiously interforing with the germination of the seed at a future season. Where at this time the suitability of the soil remains doulfful, a timely loosening and prepariug of it in strips and patehes ie resorted to to insure success.

When the expected seeding of the trees turus out a failure, further clearing is carefully avoided to prevent the deterioration of the soil or overgrowing with weeds. If, however, the season is a favorable one, and produces suficient seed, and the young plants germinate, this felling is soon extended to a greater mumber of trees, to admit. more light and dew to streugthen the young plants.

For the purpose of getting the seed worked into the ground, herds of swine, cattle, \&.., are often driven through the forest with good effect.

Seed beds are sometimes established in the neighborhood of a forest at the same time, to furnish young plants for the filling up of vacancies, which, however, are also ohtained nearly as good out of the torest itself trom platere where the plants stame thiek enongh. Altogether the abling of the naturail reproduction hy artificial means, cither sowing or planting, is at the present time generally resorted to at ouce, as such meas-

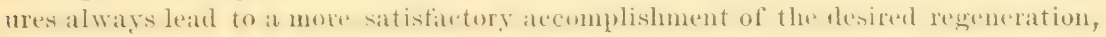
and save time.

The third felling is called cutting for light, as its chief purpose is to almit light and air in greater abundauce as the yomug plants require it. This is generally anmmenced when the seedlings are two years oid. It is also regulated very mur ho hy circumstances, and while in the one case the forest trees may be required longer on account of the spring frosts, so very injurious to the young beech, in others their early removal is. necessary, even if an increase in size be sacrificed, for the establishment of the young llees. Neither do partial failures prevent the removal of the old trees, but are resorted to at once by sowing or planting as the safest and puichest mode of securing the establishment of the young forest.

After the third or light felling follows the gradual removil of the old trees, or fimal clearing, which is regulated in the tirst instante also by the recurirements of the youmg trees, and after this by the fixed yearly out-turn, as laid down in the working plan. As a general rule, all these fellings are carried out grablually, without causing sudfen chaures in the forest. 'The alding of natural reproduction is either accomplisherl by sowing, if failures are peleeptibly early, anch as nou-germination of the secel or deatle of the seedlungs; or by planting, if the seedlings get destroyed later by spring frosts, or are choked by weeds. The sowing is carried ont in the forest in strips two feet wide, in furrows, or in patches two to three feet square, prepared by hoeiug for the purpose, and by loosening and leveling of the soil, while planting is done by seedlings two to three feet in height taken from adjoining nursers beds, or-from spots in the forest where there are more thau aro necessary.

"It is evident," says Mr. Mamu, "that if, with all this care and attention to aid natural reproduction, still occasional failures occur, how unreasomable it is to expect forests in India to keep in an equally rich and thriving condition if left to themselves. or worked only with a view of extracting the timber from them." I would also apply the rewark to Canada, and observe also that Captain Clarke respecting India, and Hon. M. Joly concerning Cauala, make precisely the same statoment, to the eftect. that the forests in both countries, cut over aud carelessly mauaged, are often, so far as any available supply of good timber is coucerued, ouly forests in appearance.

It may be noticed that the beech, of all other trees, is said to improve the land, forming a rich vegetable mold, to gain the benelit of which other trees-oak, ash, maple, larch, Scoteh fir-are planted among the beeches and do well. I may notice here that in Canada, while clearing the forest, this dir not appear to me. I generally found the maple on the richest laud, and where beech were intermixed a lighter loam. 
One description of forest much used in Germany is called "Middle Forest." It contains a number of high trees eut at long intervals for timber, and below them a copyice (smaller trees growing from roots of previously existing trees, and which will themselves, when cut, be succeeded by similar ones) cut at much shorter periods for firewood. In cutting the coppice, young trees are left to replace the tall ones when eut.

A method of planting used here should be noticed. A small spade of solid irou, about twenty pounds in weight, fourteen inches long, seven inches broad at top, five at bottom, with a handle four inches long, is driven into the ground, and bent to all sides, then drawn out. The plant, three to four years old, of beech, spruce, or oak, \&e., is dipped into a thin mixture of loam and water, which adheres easily. In this state it is pushed with its roots into the hole as far as possible, and with continual shaking, by which the roots get straight down into the hole, drawn up to the level at which the plant should stand. Here it is held by one matu, while auother drives in the spade a second time, about three inches from the first hole and parallel with it, and first presses with its point towards the first hole, and then with the broader part, by which means the plant gets very firmly pressed into the soil. If necessary the ipade is driven in a third time, to close up the secoud hole slightly. The soil is then beaten firm with a mallet all round the plant, but not striking closer than three inches. This mode is very snccessful; it is carried on without preparing the soil, and answers in stony ground, on account of the strength of the spade.

On the Harz Mountains (the scene of many a supernatural legend) are vast forests of spruce, kept with much care. One remarkable point in the management is the Government seed-drying kiln at Westerhof, for getting the spruce seed out of the cones and cleaning it of wings, which is carried on here extensively, the spruce being plentiful, of excellent growth, and producing exceptionally good seed. The cones are collected by contract work, and varies according to the seasons, if plentiful or otherwise, and generally enables the workman to earn 50 cents to 75 cents per day. After ill the Goverument stores are fillech, private persons are allowed to collect, for which the person has to pay a small sum per season. In the cones the seed remains good from seven to eight years. The Government kiln turns out about $180 \mathrm{ewts}$. per season, while private parties in good seasons have turned out as much as $1,600 \mathrm{cwts}$. besides. The cones, when first brought in, are stored in large rooms with perforated walls, so as to admit a free current of air through them.

The kiln itself consists of three rooms, the center one of which is heated by means of a large oven, from which large iron pipes, six inches in diamoter, pass twice through the room before they enter the chimney. This room is separated by walls, in which there are holes of nine inches, from the two outer rooms, in which the cones are being dried. By means of these holes, which can be elosed at pleasure, the temperature in the drying-room is regulated and kept between $1222^{\circ}$ and $128^{\circ}$ Fah. The drying is done in large wire drums, out of which the seed falls on the floor of the room. There are twelve in each room, and are turned from the outside of the room, where it is cooler. They are filled in the evening, the temperature got up, and so left for the night. The next morning the fire is lit agaiu and, the drums being turned every half hour, by night the cones are empty. Half the cones are used to heat the kiln; the rest sold for fuel. It costs Government about six cents per pound. What is not needed is sold at nine.

It is noticeable that the spruce woorl, amoug other uses, is ground into pulp for paper maunfacture, several mills in the Harz Mountains being employed in this manner. It might be worth consideration whether, under an improved system of forestry, the waste wood left in such quantities in hewing and score-hacking could be, in our great Canadian spruce forests, so employed.

It will be well to give an account of the method of reproducing and earing for sprnce forests, both because our own forests will soon need replanting and to givo some idea of the care taken in maintaining woolland property in foreign lands. 
Natural reproduction of the spruce is seldom attempted, as too slow and uncertain; but if there are thriving naturally some clumps of any extent they are kept up. Almost all spruce forests are regulated high forests, with complete clearings either resown, which is still preferred bs some, or planted, which is by far the most general mode of establishing or re-establishing spruce forests. If somn, lines about two feet in width are prepared ly clearing the weeds, fee, off the grouml, and placing this at the edge of the lines to prevent the wind blowing among the seed or rain washing then ofi. The soil on these strips is sometimes loosened and lett as it is if the seed is to be sown broadcast. If the seed is sown in rows small furrows are made. Between the strips ground twice as wide is left. For plautations the seed is sown in serd-beds, which are good, even, and sheltered pieces of land, about half an acre in size and well dug up, afterwards leveled and ocensionally slightly manured by the ashes of the weeds, remains of wool, \&e., collected on the surface, lnought together and burned, and afterwards mixed with the soil. These seed-heds art nsually in the immediate neighborhood of the ground to be planted and have to be fenced in. If the seedlings, after they are three or four jears old, have to be removed from here at once to the spot where they are to remain, the seed-heds lave to he linger, especially if the young plants are to be planted out in numbers, $i$. e., three or four in one hole. In the latter case the seed is sown generally in furrows, one foot apart, as being more envenient, and requiring here in the hills about seventy-five pounds of seed for half an acre, Which is sufficient to plant filty acres of forest. The better plan, however, is to have the plants from seed-beds, after they are two rears old, transplanted siugly into a nursery at about seven inches distance, where they remain until they are four or five years old; this, however, requires as much space again for the nursery as for the seed camp. Not unfrequently four to six year old secellings are taken from the adjoining forest, where they are generally so close as to permit of the removal of many of them; and this is the most inexpensive way of procuring secellings in linited mumbers. Where there is a clemand for thimniligs the planting of three or fomr plants in one hole recommends itselt:. If it is likely that the gronnd get rum over raphilly with weeds, or the soil dried up by the sun, the replanting is dome as soon aiter the remoral of the old forest as possille, whilst where the dangtr from insects, esperially the small beetle, is great, the ground is let lie two or three years first. Planting is done in autumu as well as in spring, but the latter is preferred. Suruce is plauted four or tive feet apart.

To protect the spruce forest against damage from insects the forester has to be constantly on the alert, as they are many, and if not checked in time great damage is done by them. The most destructive noticed was the ordinary spruce bark beetle, which attacks the bark of living trees, and had, in some of the localities visited by the commissioner, destroyed so many trees that, when the diseatsed were removed the forest had hecome so open that the wind wombl som have remeved the rest had they not been felled. Experienced men are told oft to gnard andinst this diuger ly going through the forest to search for the trees attacked by the beetle and fell and bark them to prevent the spreading of the insects. In most cases they are quito able to hold the insects in check. These generally attack trees loosened in the roots by wind, known after the beetle gets in by their foliage turning yellow. In spring, when they

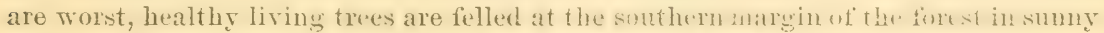
spots, for the purpose of attrating the beetle. Such tres arm often finl of them three or four days after being felled. The trees attacked are barked, which destroys the larva if not too far advanced; if so, the bark is burned. 'T'o prevent any escaping while barking a cloth is spread under the stem. The timber beetle, which attacks new felled trees, going deep into the wood, is also common there and is watched for closely. For the young plantation of spruce the first mentioned is the most dangerous as it eats off the bark above the roots and kills the tree. Fresh pieces of bark a foot sinuare, inuer side domn, are laid aromul before or atter planting. The beetles go under and are caught and killed. The bark is examined every morning.

4468 LOR-3 
SILVER FIR AND SPRUCE IN THE BLACK FOREST.

The Black Forest monntains are the home of the silver fir. The winters are sererefive to eight feet of snow on the hills from November till April; three feet in the valleys from December till March. They are partly regulated forest, in which, howerer, a gradnal felling for their reproduction is carried on over one-third or one-fourth of the whole area at once, from which every year during thirty or forty years the largest trees are removed, while the rest are allowed to grow larger during the remaining rears. This is done, as the price these large trees fetch is much higher in proportion than that of the smaller ones, and all are felled and removed in one piece if possible. Natural reproduction is chiefly resorted to in these forests, which, in consequence of the young plant growing well in the shade of the old trees, is very easily accomplished, even thongh it is extended over such a long period as thirty or forty years. To be able to keep as many trees as possible groming on the lands on which the regeneration of the forest is going on, the branches up to one or two-thirds of the height of the tree are samn off to admit air and light to the joung plants below, which does no harm to the silver fir, but, on the contrary, is said to aid the more rapid increase of the trunk, while the branches are used for litter. This sawing off of the branches is commenced from above by men who earn abont forty-five cents a day. Regular seedbearing seasons occur at longer or shorter intervals, but nearly every year there is sufficient seed to increase the number of roung plants where it is wanted. Moss cover is very favorable for the germination of the seed, whilst in such places as get covered with grass or weeds, or where for other reasons the seed does not germinate freely, the soil is at once prepared, by elearing and slightly loosening it in strips and patches, for the reception of the seed, the germination of which is thus facilitated. If the open space in the forest is so large that the seed from the old trees does not reach the whole of it, sowing by hand is resorted to early, so as to let the young plants be as nearly as possible of the same age. If, by the time the old trees are nearly all removed, there are still some parts not covered with young trees, planting is resorted to. For the better growth of such planted trees the existing groups are somerhat rounderl off, to avoid the young trees planted luaving to struggle with the others, perhaps already twenty to thirty years old; and where, on incompletely stocked spaces, which have to be filled up by planting, there are single trees of some twenty or thirty years, they are cut down altogether; or, if they are standing in numbers, and are not quite so large, some of the lower branches are lopped off the outer ones, so as not to interfere with those planted. These plants are either taken from nurseries or out of the forest, if the latter have not grown in too deep shade, which wocld render them liable to suffer on being removed to open places.

The seer is collected with some risik from the trees in October, before the cones open and it falls ont. As the seeds are very oily, they are best kept in the cones or sown at once. The sowing is done in prepared beds in rows four inches apart, and after germination the ground is covered with moss to keep in the moisture. The seedlings one year old are transplanted into rows six or seven inches apart, and three inches between the plants in the rows, after which the soil between them is also covered with moss. Here they have to remain for two or three years before they are fit for transplanting. Shade from the side is very beneficial for the seed beds as well as for the nursery. Plantss from the nursery are preferable to those out of the forest; and the latter, when used, are as a rule removed with some of the soil adhering to the roots. Planting is better done in spring than in autumn, and in the usual way, the roots of the young plants being cut as may be necessary. They have to be sheltered as far as possible against sum, dryuess, or spring frosts, and the plants as a rule thrivo better nu the ronl northerly and easterly slopes of the mountains than anywhere else. The silver fir srows very slowly at first, and does not get much higher than six inches in the first four or five years. At the age of twenty-five years it begins to grow very fast, and increasess most between the ages of eighty and a hundred and twenty years. 
It likes best a deep, cool, moist, and loamy soil with a corering of moss, and sends its roots deeper than the spruce, in cousequence of which it suffers less from wind and storm than the latter. There are many spruce intermised, used when natural reproduction of the silver fir fails. Thinnings are necessary in the thirtieth year, and have then to be repeated every teuth jear, till the gradual felling of the largest trees commences. These follings are regulated by the needs of the young scedlings, and are carried out only sufliciently to admit light to the young plants, leaving as many of the old trees to stand as can be permitted.

Moorpan.-In Hanover and elsemlere, where the Goverument are bringing up thousands of acres of heath for the purpose of planting forests, great difficulty is found in penetrating and converting into good soil a bard layer called "moorpan." "This is broken by plough aud pickase, aud Scoteh firs planted, whose deep tap-root passes down into the layer of better soil below. The Goverument pay about $\$ 11$ an acre for the land.

\section{FIANCE.}

The administration of forests in France is intrusted to the ministry of finance, and the head of the Department is the director-general, assisted by two administrators, one charged with the management of the forests and the sale of the products, the other with the police of the forests and the forest laws. In the departments thereare thirty-two conservators, each in charge of one or more departments, according to the extent of forests in each. The immediate supervision is intrusted to inspectors, trho are assisted by sub-inspectors and gardes-generaux, who live near, and persoually superiatend all operations and work of the forest guards. The brigadiers and forest guards live in houses in the forest and serve as a police over a certain rauge. 'They are required to be present at all operations, and to go round their rauges at least once a day to report any violations of forest law that may take place.

The saw-mills in the forests are usually owned by the Government and hired at a certain rate to tho wood merchants, who buy the enttings. The timber is allowed to be sawn up before it is inspected and marked by the forest guard under the superintendence of an inspector.

The forests under the management of the bureau are (State and Commune) about 7,500,000 acres. There were nearly a million more, which went with Alsace and Lor- raine to Germauy. Also, there are in France 15,000,000 acres of private forests.

Of schools of forestry, the French have, at Naucy, one of the best in the world, where prupils are instructed both experimentally and theoretically in all forest learning, the collegiate home studies being constantly varied by exclirsions of parties of pupils, under charge of professors, to those forests where, at the time, most can be lemrned. Proficiency iu these school forms, of course, a strong recommendation to future advancement in the Govermment or private forests service. For admission to the school candidates inust bring a letter of anthorization from the director-general of forests, which can only be obtained by those from nineteen to twenty-two, without infirmities, and having a diploma of bachelor of letters, or attainments in classical studies to warrant such diploma. They must also have an income of $\$ 300$ per anmum, or a pledgro from frieuds to provide it and $\$ 120$ afterwards till employed as garde-general on active duty.

In the difticulties which have hindered the efforts being made, especially in America, to preserve a due anount of forest, one of the most formidable has been the disinelination to interfere with private rights. It will be of service in Canada in this matter to notice how summarily, in France, this matter has been inanaged. I will therefore quote the principles of law upon which the forest code of France is foumded, as stated with great precision by Professor Macarel (a writer deservedly of tho highest estimation) in his "Cours de Droit Administratif." As they embrace views applicable in other comtries under like necessities-being, in fact, an extension of the right of eminent domain, or that maxim of Roman law, salus populi suprema est lex-they will be especially germane to our puxpose. He says: 


\section{"Restrictions implied in the free enjoyment of the soil.}

"As to the woods and forests:

"The preservation of forests is one of the first interests of society, and cousequentis one of the first duties of government. It is not alone from the wealth which they offer that we may judge. Their existence is of itself of incalculable benefit, as well in the protection and feeding of the springs and rivers as in their prevention of the washing a way of the soil from mountains, and in the beneficial influence which the exert upon the atmosphere.

"Large forests deaden and break the force of heary winds that beat out the seeds and injure the growth of plants; they form reservoirs of moisture; they shelter the growth of the ficlds; and upou hill-sicles, where the rain-waters, elecked in their lescent by the thousand olsstacles the present by their roots and by the trunks of trees, have time to filter into the soil, and only find their way by slow degrees to the rirers. They regulate, in a certain degree, the flow of the waters and the hygrometrical condition of the atmos!here, and their destruction accordingly iucreases the duration of droughts and gives rise to the injuries of inundations, which denuce the face of the mountains.

"Penetrated with these truths, legislators have in all ages made the preservation of forests an object of special solicitude.

"Unfortunately, private interests-that is to say, the action of those who do not directly feel the power of the Government-are often opposed to this great national interest, and the laws framed for protection are often powerless.

"In France, the ordinances prior to the revolution carriod too far the restrictions imposed on private owners. The new regulations fell into the opposite extreme, and allowed the proprietors free and absolute liberty to dispose of their woods.

"A large destruction followed this imprudent translation from excess of restraint to excess of liberty. The proprietors abused this unwonted freedom, and clearings multiplied indefuitely, withont distinction as to the places where they were made, so that in many localities the rushing down of the denuded soil and the deforesting of mountains caused the soil needed for vegetation to disappear and left the rocks naked. The rise in the price of wood and the easy and certain resourco offered to proprietors in the clearing of a planted tract, when compared with the remote and eventual advantages offered in their preservation; the hope of compensation, and, beyond this, the advantages, in one way aud another, of cultivation, may be recognized as among the causes which sufficiently explain the indncements offered to mauy of these proprietors, which led them to undertake these clearings."

I would here notice that this is precisely what we have been doing in Canada, and that the ill effects which followed in France will surely in no long time be felt in Ontario. They are already felt; we have not the climate we had, nor the favoring moisture when most needed. Yet we conld get along as we are. But that is just what is impossible. We must, while there is time, use some means of averting the evil, or we shall certainly become much worse off than we are. M. Macarel goes on:

"At length, this progressive deforesting of the soil of France, joined with the incessant need of firewood, and the demand for wood by maunfactories and ships, have, during forty years, made sad havoe with our forest wealth.

"A renewal of the ancient prohilitions by the law of ? Floreal, year XI, was deemed necessary to oppose this excessive clearing of woods by private owners. It was accordingly decreed that, during the twenty-fire years dating from the date of the promulgation, no wood should be cut or carried off unless sis months' notice had been given by the proprietor to the forest conservator of the arrondisement of the district in which the wood was located. Within this time the forest administration might olject to the clearing off of the wood, and was charged to refer the question before the end of this time to the minister of finance, upon whose report the Government might definitely decide within the same time. It therefore resulted in this, that to make a clearing an authorization precedent by the administration was necessary, and 
that if the administration thought proper not to grant this, the proprietor was restrained against cutting.

"Thus, according to this branch of agricultural industry, the general law of Irauce is, that owners are free to vary, within certain limits, the cultivation and working of their lands; but as to woods and forests, the public interests demand that individuals shall not be free to clear them from the soil whenerer they please. From hence it follows, that the administration has a right to prononnce its prohibition against clearing whenever it is deemed that the public interests require that this be doue."

The penalties for clearing when forbilden are, I may state, a fine of about sog per acre, aud compulsory replanting within three years. This law was, I conceive, in full force in 1874, as this quotation forms part of a report to the United States Congress of that year. It prolubly is in force still, aud justly so. The voice of the people, not of solitary citizens, should decide in so important a matter as deforesting a country.

The French Govermment have, at great expense, replanted rast and almost barren districts; they lave also established great forests along the sea-shore, where formerly the sand threatened to destroy whole departments, and have arerted the evil. But the chief means is the prohibition of clearing; for it is the interest of an owner who does not clear to plant and improve his forest, so as to receive an increased incomo from the trees arriving at maturity in increased numbers yearly.

SWITZERLAND.

In no country in Europe has the waste of forests been more rapid or destructive than in Switzeriamd, and in nome, perhays, has this improvidence been followed by more disast rous result. The woods, being considered common property, were uprooted; and the soil on the monntains being exposed to the wash of the rains, was minilly carricd away, leaving broad areas of naked rock, from which the water would at ouce sweep down the valleys in sudden and destructive inundations. The antumn of 1863 is memorable on account of these floods.

Public attention has, however, been thoroughly awakened, aud active measures are in progress to remedy, as far as may be, these evils. The cantons which have charge of these operations have for some time, at great expense, been constructing worlis to control the streams, and planting trees wherever practicable.

I would here remark that this is a very difficult matter compared with what it might have been. It is easy to preserve a forest on a hill-side, but the suil once washed to the rock, it is another matter. I could point out places ip Outario where splendid forests stood, and yet might have stood, now for many miles.

\section{"White rock and gray rock,}

Barren and bare."

The matter is now in Switzerland taken into the hands of the vational Government, and the following article gives the idea:

"ArT. XXII. The Federal Union of Switzerland has the right of supervising struetures for the protection of water courses, and of the forest police in mountain regions. It will assist in protective struetures for water courses, and in the planting of forests at their sources. It will enact the requisite regulations for maintaining these works and the forests now existing."

ITALY.

Soon after the present Kingdom of Italy was established, a central forest school was organized near Florence, under the direction of $A$. di Berewger, formerly in the Austrian forest service of Venezia, aud author of an excellent work on the history of forest management in Itals. The school is located in the spleudid silver fir forest of Vallombrosa. We all remember

"Thick as autumnal leaves that strew the brooks,

In Vallombrosa." 
This is below the erest of the Apennines, on their western slope, about twenty miles east of Florence. In winter it is transforred to a lower station at Paterno, in the region of the olive. Italian forest literature of direct practical application is comparativeiy modern, but of late the publications of the ministry of agriculture, to which sylviculture is entrusted, contain much that is valuable. The tro most important of these give the statistics of forests and the forest law of Italy. There are over $5,000,000$ acres of communal forests, over $6,000,000$ of private forests, and ouly 500,000 acres of State forests. One-fifth of the land is in forest. This is scant enough, apparently, or the nominal forests have been culled to depreciation, for we are told that-

"Projects of a general forest law for the whole of Italy have been repectedly submitted to the Italian Parliament. The evil effects of denudation have been severely felt in many parts of the country, aud the aim of these proposed legislative enactments has hittherto been to guard against further misehief by determining beforehand which lands shall, in the public interest, be clothed with forest or liept under forest, and then to place the whole of these lands nuder the supervision or control of the public forest officers without distinction, whether they belonged to state, village, commune, or private persons. From a report with which the minister of agriculture snbmitted the project of a general forest law in 1870 , it appears that the finaneial exigencies of the country had rendered imperative the alienation of the greater part of the forests at the disposal of the State, and that it was only intended to retain a limited area of State forests, mainly with the view of supplying the timber required by the navy, and the forests required for this purpose the bill proposed to declare inalienable.

"Thus, with regard to forest matters," says Captain Walker, "it seems probable that Italy will pursue a policy different from that which has of late years been initiated in most provinces of India. In those provinces we ackuowledge the necessity of maintaining certain areas under forest, or of clothing them with forest when they are bare; but we do not expect any satisfactory snecess in those attempts, unless the forests to be thus maintained or created are under the enitre courtol of the State, and we entertain no serious hopes of effecting any real good by the supervision of private forests, or by any general kind of control over communal forests, unless the administration or management of such communal forests can be vested entirely in the hands of the public forest officers.

"In those provinces, therefore, of the Indian Empire, to which I now refer, our principal aim is, in the first place, to consolidate the State forests wherever the State has suitable forest lands at its disposal; and we hope that eventually, when the ma. jority of puhlic forest officers shall have aequired that professional knowledge, skill, and experience which is necessary for a satisfactory management of forest land, that they may be found competent not only to manage the State forests entrusted to their charge, but also to induce la'ge landed proprietors to follow their example in the management of their own estates, and, if such should ever be found necessary and expedient, to exercise au efficient supervision over private and communal forest lands; but we think that any attempt to exereise supervision and control over private and communal forest lands through the agency of forest officers who have not actually charge of public forests entirely under their own control, and who cannot point to the management of their own forests as an example to be followed in the manageinent of the private or communal forests, would lead to unsatisfactory results. The further development of the general forest policy in Italy will doubtless be followed with great interest by Indian foresters, and on this account it appeared to me right to add the present remarks."

It may be valuable here to notice that in this, as in o her points, the practical ideas of the Indian commissioner might well be applied in Canada. There is good reason to fear over-deuudation here; there is also reason to believe that we shall have an interval in which to take measures for aroiding the evil. In that interval the course 
stated by the commissioner as likely to be followed in India might, it appears to me,

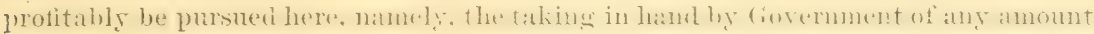
of forest fit for the purpose, and which could be spared from the cperation of the system at present pursued, and preserving them on the Enropean plau. This will further on be more fully treated.

\section{IRUSSIA.}

In this vast empire, where, as in the United States, we have been acenstomed, to believe the forest is interminable, and where, in fact, the amount of woodland in the northern two-thirds is more than twice as great in proportion to its area as in the United states, the Government has turned its attention energetically to the suljeet of forestry, and has undertaken to establish by regulation conservative measures. As yet, private persons aud establishnents owaing forests enjoy the absolute right to cut and clear at will. But theso do not own nearly so much as the Government, which

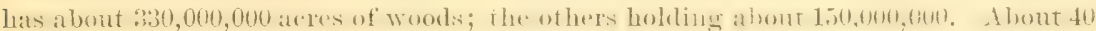
per cent. of the country (Russia in Europe) is timbered. I must remark that this amount, after so long an occupation, shows that the timber lhas been taken some care of already. For the immense Government woods, they have been placed under the care of the minister of public donains, who has a director of the forest department, and the organization of the service is very complete. For the purpose of titting young men for the duties of forest agents and agricult urists, either for the (ioremment service or upon private estates, two special schools of agriculture and forestry have been established-one at Saint Petersburg and one near Moseow. The course of instruction extends through three or four years, and the schools are placed near forests, where every detail is illustrated. There is also another forest sehoul at Lissino, of the secoud grade, where the course is very. practical.

SWEDEX.

In 1859 a bureau of forest administration was created. Forest regulations, hotrcrer. extend back to 16 . and protect from eattle two trees for each one cut.

In 1868 a commission was appointed, under the direction of Mr. E. V. Alinquist, to incquire into the need of further legislation, and in December, 1-ien, lee subnitterl a report with a bill, making 392 pages, besides numerous tables.

One clanse in the reported bill is a compulsory feature, which, thongh less stringent, is in the spirit of the enactments now in force in most of the countries of entinental Europe, namely, forbidling trees to be eut for sale smaller than eleven inches at the butt, or eight inches, sixteen Swedish feet therefrom.

INDIA.

The necessity of preserving tropical forests has, fortumately, attracted the attention of Goverument in British India, where the importance of maintaining an equilibrinm of temperature and hmmidity is of much immediate consequence to the social relfare; and the growing demands of railroad nse, and the varions applications of the arts, render it a subject of direct practical utility.

The matter has beeu agitated since 1850 , and in 1864 Government laid the foundation of au improred general system of forest arministration for the whole Indian Enpire, having for its ohject the conservation of state forests, and the development of this source of national rrealth. The experience acquired in the forest schools of France and Germany has been bronght to apyly in this great national umbertaking. Among the more important general principles laid down for the cxecution of this measure is that all superior Governmeut forests are reserved amd male inalienable, and their bonndaries markerl out to distinguish theur from waste lands availathle for the public. The act of 1 ir 64 , defining the wature of forest rules and penalties, has been adopted by most of the locil goveruments, and tho esecutive arrangements aro 
left to the local arminisirations. Various surveys have been made to obtain accurate data conceruing the geographical and botanical characteristies of the reserved tracts, and the kind of timber best adapted for various localities has been carefully ascertained.

In 1866 , the Government resolved upon sending out five joung men, duly qualified by edncation in the forest schools of France aud Germany, for the forest department of India. Au arrangement was nade the same year by which forest officers in the India service, who might ehoose to come to Enrope on furlough, would be able to increase their professional lnowledge by studying forest management aud other subjects connected with forests in Great Britain and on the continent. A number of officers have availed themselves of these arrangements, and some of their reports have been published.

Of these, that by Captain Walker and that of M. Gustav Maun I have largely usod elsewhere, as the reader will have observed.

"At the moment of our writings," says the author of a report from which I have obtained unch, presented to the United States Congress in 1874, "the public journals are giving most painful accounts of the distress in India from famine. From a careful study of this subject, wo cannot doubt that this calamity is due to the fact that the forests have, of late years, been swept off by demand for railroad and other uses much more rapidy than formerly, and that the exposure to winds and sun thus oceasioned mar have largely contributed to these painful results. The remedies are to be sought in the restoration of that due proportion of forest-shade upou which agriculture depends for success. If the officers to whom the opportunities for European observation fall, improre them as well as some reported by Captain Waller, we may reasonably hope for a radical, though not an immediate, rest orat ion of abnudaut harvests throughout the vast countries of India."

Now, since this was written, we have Sir Richard Temple's valuable book, "India in 1880," which I have noticed before. This gives us some idea of what has been commenced by the gentlemen who have been writing the reports we have used. He says:

"The Government of India has enacted a law regulating all matters connected with forest conservancy, and the provisions of this law are heing carried into effect lyy the several local goveruments. The forests are divided into two eategories: first, those which are 'reserved' being preserved and worked through state agency, in a most complete manner; secondly, those which are 'protected' being preserved less thoroughly. The best timber markets are mainly supplied from the 'reserved' forests. Care has been taken to determine what tracts shall be 'reserved' and 'protected,' and to mark off their boundaries. The area thus defined in the several provinces already, or likely to be defined ere long, will prove to be hardly less than eighty thonsand square miles for the whole empire. The primary object of the administration is to preserve the forests for the sake of the country. Due attention is also given to the financial out-turn; much income is already secured. The expenditure is over $\mathscr{L} 500,600$ annually, but the receipts amount to nearly $£ 700,000$, and in time the forest department will have a prosperous revenue.

"The superior officers of the department are for the most part British, trained in the forest schools of Frauce and Germany. The inspector-general of forests with the Government of India is Dr. D. Brandis, whose services to the empire have been conspicuous in organizing a system of forestry which is sound and scientific, and is yet adapted to the circumstances of the country. Instruction in forestry is afforded to uatives also; forest schools are established for them, and in time they will take a large share of the administrative work.

"As might be expected, the system of forest conservancy, thougl generally accepted by the natives who dwell near the 'reserved' and the 'protected' tracts, is sometimes opposed by them. There must always be some danger lest the foresters should, in their zcal for cons rancy, infringe upon the prescriptive rights of the inhabitants. The local eivil authorities are vigilaut and prompt in asserting and vindicating the 
rights of the people in this respect: for the recognition of which rights. inderet. ample provision is made by the law. They should, however, be careful to support the forest officers in the execution of duties which are of the utmost consequence to the welfare of the country. Many of the hill tribes habitually burn patches of valmable forest, in order that the ashes may so fertilize the virgin soil as to render it capable of producing a crop withont tillage. Having reaped one harvest, they leave the spot marked by charred stumps of timber trees and move on to repeat the same ravage elsewhere. This barbarous and wasteinlly destructive practice is gradually and cautiously checked by reclaiming these people from agrienltural savagery, and inducing them to plow lauds and raise searly crops by orlinary husbandry.

"According to the latest returus there appear to be 29,600 square miles of demareated reserve forests, 3,500 square miles of protected areas, and 35,000 square miles of unreserved forests, or 68,000 square miles in all. This appears a comparatively small area for so large an empire, especially when it is remembered that of this not more than one-half is effectually preserved. Some extensive forest tracts exist, however, in the Madras Presidenc5, of which a return remains to be rendered. There are, further, 31,000 acres of plantations in varions districts."

These plantations, I may remark, are those commenced by the foresters under Dr. Braudis, and are being every year added to at the rate of some thonsands of acres. It may be noticed that the forest officers trained in Europe for India, and at work there nnw, number forty-six ont of a staff of ninety-three, who have, of course, an immense number of subordinates.

Concerning other comntries, it may be generally remarked that all the nations of continental Europe are moving in forestry matters, aud that there are many schools besides those I have mentioned.

4468 LOR -4 








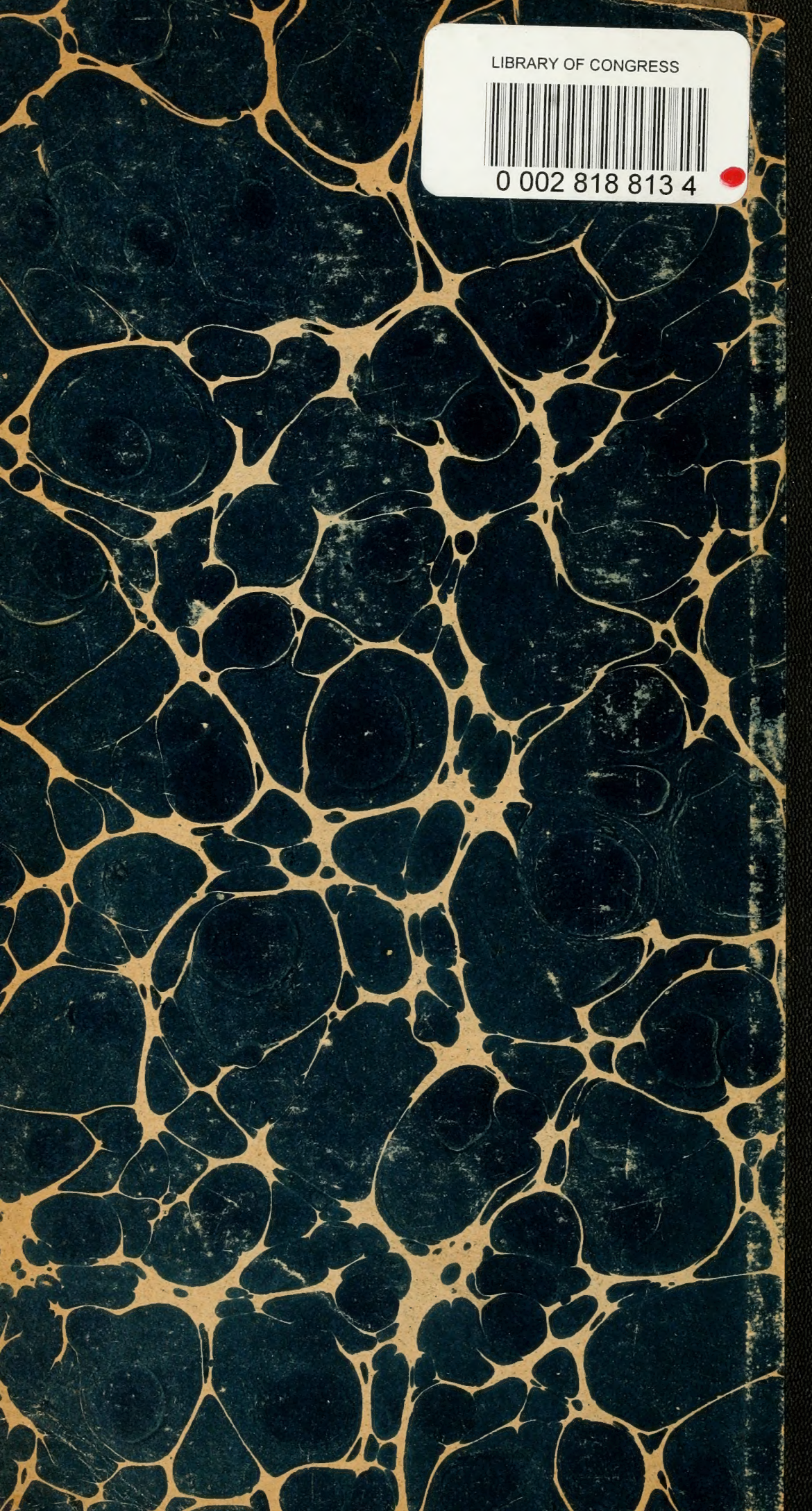

